\title{
Otra vuelta de tuerca. Notas para un refinamiento de los conceptos y discursos críticos sobre "terrorismo islámico" y violencia política
}

\author{
Alice Martini y \\ Francisco Javier Peñas Esteban*
}

\section{RESUMEN}

El conflicto actual entre mundo occidental y el "terrorismo islamista" es algo que va mucho más allá del problema que supone la violencia - trágica y dolorosa - que ejercen y en la que se basan estos grupos. Efectivamente, la brecha que divide a estos grupos de nuestras sociedades es civilizatoria: se sustenta en diferentes y antagónicas propuestas sobre cómo debe organizarse la vida social. En este sentido, el choque es entre una modernidad occidental y un modelo de organización social - también modernoque no separa lo político, lo religioso, o social, etc. Sin embargo, los conceptos políticos occidentales "secularizados" siguen siendo de corte teológico: de aquí un choque de "civilizaciones", entendidas como diferentes modelos de organización de lo social y de lo político.

\section{Palabras clave}

Secularización; modernidad; terrorismo islamista; choque de civilizaciones.

\section{TITLE}

Another turn off the screw. Notes on the concepts and critical discourses on "Islamic terrorism" and political violence

\begin{abstract}
The current conflict between the Western world and "Islamic terrorism" derives from something more than the mere problem of the - tragic and painful - violence these groups use. In fact, the gap that divides them from our societies is a civilizational one as it is created by different and antagonist conceptions of how the social sphere should be organized.There is a clash between aWestern modernity and a model of social organization - which is also modern - that does not separate the political, the religious and the social sphere. Nevertheless, the "secularized" Western political concepts may also be considered theological ones, something that creates a clash of "civilizations", a clash of different models of organization of the social and political sphere.
\end{abstract}

\section{KEYWORDS}

Secularization; modernity; islamic terrorism; clash of civilizations.

\section{DOI:}

https://doi.org/10.15366/relacionesinternacionales2018.39.001
Formato de citación recomendado:

MARTINI,Alice y PEÑAS ESTEBAN, Francisco Javier, "Otra vuelta de tuerca. Notas para un refinamiento de los conceptos y discursos críticos sobre "terrorismo islámico" y violencia política", en Relaciones Internacionales, $\mathrm{n}^{\circ} 40$, 2019, pp. II - 50 .
*Alice MARTINI, Coordinadora del Grupo de Trabajo de Estudios Críticos de Terrorismo (Critical Terrorism Studies Working Group BISA).Alice trabajó bajo la dirección de Francisco Peñas Esteban durante años, con quien estaba escribiendo este artículo que hoy publicamos.

Francisco Javier PEÑAS ESTEBAN, fue profesor de Relaciones Internacionales en la Universidad Autónoma de Madrid hasta su jubilación, así como cofundador $y$ director durante varios años del Máster de Relaciones Internacionales y Estudios Africanos. Entre sus libros publicados más conocidos puede contarse las dos siguientes obras: Occidentalización, fin de la Guerra Fría y Relaciones Internacionales (1997),y Hermanos y enemigos. Liberalismo y Relaciones Internacionales (2003). Fallecido hace un año, Paco fue fundador de esta revista en la que, en su memoria, publicamos su último artículo.

Recibido: 30/08/2018 Aceptado: I5/I I/2018 
"No hay peor argumento contra una teoría científica o filosófica que señalar sus presuntas consecuencias políticamente perniciosas"

Hume

\section{$\mathrm{I}$}

\section{ntroducción}

Nuestra crítica' a los discursos académicos mayoritarios por no decir a los discursos oficiales y oficiosos sobre el terrorismo se basa, como desarrollaremos más abajo, en dos pilares, dos inspiraciones: la primera, que "terrorismo" es una etiqueta lingüística que construye realidad $d^{2}$. Ésta distingue y aísla un tipo de violencia como si fuera ontológicamente distinta de otros tipos de violencia y así la convierte en enemigo.Y en segundo lugar, que el concepto "terrorismo" desplaza el objetivo de esta violencia de lo político a lo civilizatorio-teológico, creando un enemigo absoluto (en términos schmittianos) con el que no se puede negociar, convivir, etc., y al que sólo se puede aniquilar.

Lo que pretendemos con este trabajo es dar otra vuelta de tuerca más a lo anterior, refinar nuestra crítica al mainstream académico de los estudios sobre terrorismo. No queremos volver al pasado académico (como podría ser el de Huntington) que no nos convence e incluso nos irrita, pretendemos ir más allá. En su artículo de $1993-$ y, posteriormente, en su libro de 1996Samuel Huntington ${ }^{3}$, con su famosa teoría, anunciaba que el rasgo fundamental que diferenciaría las relaciones internacionales del siglo $\mathrm{XXI}$ sería la división del mundo en civilizaciones y sus consecuentes e inevitables choques y conflictos. Estos se verían causados por la naturaleza tan diferente y contradictoria de los muchos sistemas de valores $y$, a veces, por el mismo carácter violento y agresivo de algunas de ellas.

Sin embargo, esta teoría fue ampliamente criticada y rechazada por muchos conocedores de las relaciones internacionales, por su visión simplista y no acertada de un mundo tan complejo de no poder ser resumido en "nueve civilizaciones". Efectivamente, el mismo concepto de civilización no sirve de mucho en este mundo global pues no hay esas totalidades homogéneas $y$, desde luego, no parece que sean las nueve que Huntington propone, que parecen más pura invención o reflejo de las diversas comunidades presentes en EE.UU. que actores internacionales.Ahora bien, aunque compartamos gran parte del aluvión de críticas que recibió, llegados al siglo XXI, queremos empezar nuestra reflexión citando algo de su teoría. Lo que nos parece sugerente del afamado y denostado artículo de Huntington es sólo su título y, de alguna forma, la idea de que ese choque de civilizaciones - aunque las civilizaciones de Huntington sean inventadas y estrafalarias - puede marcar las relaciones internacionales del siglo XXI. No citaremos más al autor, pero, sin duda, "Eppur si muove".

Por lo tanto, seguimos manteniendo (I) nuestro planteamiento epistemológico y ontológico. Seguimos pensando con Wittgenstein que los límites de nuestro lenguaje son/hacen las veces de los límites de nuestro mundo. No nos desdecimos (2) de que en el discurso académico y político

\footnotetext{
Aquí se utiliza crítica en el sentido clásico como Crítica la razón pura de Kant o Critica a la violencia de Benjamin. No solo es el sentido de la negatividad sino en el sentido de examen, de compresión, etc., por más que si seamos críticos -negativos- con la doxa sobre el terrorismo.

2 Siguiendo a la filosofía de Ludwig Wittgenstein.WITTGENSTEIN, Ludwig, Tractatus logico-philosophicus, Alianza Editorial, Madrid, 20 I 2 [I 92 I].

3 HUNTINGTON, Samuel, "The clash of civilizations", Foreign Policy, vol. 72, no. 3, 1993, pp. 22-49. HUNTINGTON, Samuel, The clash of civilizations and the remaking of world order, Simon \& Schuster, Nueva York, 1996.
} 
occidental hay un desplazamiento en lo que se refiere al llamado terrorismo, de lo político a lo civilizatorio o a lo teológico. Sin embargo, sostenemos (3) que el situar el conflicto en términos civilizatorios o teológicos tanto por parte de Occidente como por parte de las organizaciones etiquetadas de "terroristas islámicas" tiene una base firme. En este sentido, argumentamos que hay una brecha, un conflicto de visiones del mundo y de la vida social que se narra por ambas partes, al menos, como civilizatoria.

Esta brecha es la secularización o no de lo político. La división moderna occidental de la actividad humana en esferas diferentes (lo económico, lo privado, etc.) y el abandono del recurso a un ser trascendente - ahistórico y ahumano- como motor o explicación de los fenómenos humanos. La visión occidental de lo político es secular, o, por lo menos, la secularización de la política es una ficción operativa que funciona. La visión del islam de la cual se nutre este tipo de terrorismo ${ }^{4}$, no incluye esta división y esta no trascendencia en su concepción de la vida social: no hay separación de lo religioso, lo político, lo económico, etc. En ese sentido nos encontramos con concepciones de lo social y de lo político: el desplazamiento occidental frente a la visión holística del islam.

También queremos reafirmar (4) nuestra crítica a la doxa occidental señalando que se basa en uno de los hilos filosóficos de la modernidad occidental: el que une a Aristóteles con Kant y con Arendt. Nosotros, por el contrario, revindicamos la vigencia y acierto de otro hilo filosófico moderno: el que une a Nietzsche, Weber, Schmitt, Benjamin, Morgenthau, etc. Este hilo señala (5) que la violencia lejos de ser una anomalía siempre destructora ha sido y es una constante en la actividad humana, tan conste como el conflicto mismo. Y que sólo reconociéndolo podrá atemperarse, restringirse y minimizar el daño y el sufrimiento. No es, por tanto, objetivo de este trabajo examinar (6) al Daesh/lsis ${ }^{5}$ o a al-Qaeda o las otras organizaciones "yihadistas", describir sus "condiciones de posibilidad", ni desentrañar su discurso. Nuestra crítica es a la doxa occidental y a su entendimiento de lo que se ha venido a llamar "terrorismo islámico".

\section{Nuestros pilares teóricos: construyendo enemigos a través del lenguaje}

Hasta ahora, en todos sus análisis sobre el terrorismo, los autores de estas líneas han utilizado dos relatos filosóficos: el de Ludwig Wittgenstein y el de Carl Schmitt (recuperado, posteriormente, por autores como Chantal Mouffe) para examinar el "terrorismo" desde un punto de vista teórico. En primer lugar, para acercarnos a lo que es lo que debería ser el terrorismo, hemos adoptado el punto de vista que nos proporciona Wittgenstein con su filosofía del lenguaje, resumido en la frase "los límites de mi lenguaje significan los límites de mi mundo"6. En este sentido, siguiendo también a autores de la corriente de los estudios críticos de terrorismo ${ }^{7}$, hemos definido el "terrorismo" como una etiqueta lingüística, y no como un término con un claro significado más allá de su matiz peyorativo. En este sentido, el "terrorismo" es una palabra "vacía", que tiene unas connotaciones

\footnotetext{
4 Por lo tanto, discrepamos de filósofos como Alain Badiou que sostiene que para los militantes islámicos "la religión es un pretexto, una cobertura retórica manipulable y manipulada por las bandas fascistas”. En BADIOU, Alain, Nuestro mal viene de más lejos, Clave Intelectual, Madrid, 2016, p. 57.

5 Cada una de estas denominaciones tiene implicaciones políticas en las que no podemos entrar en detalle en este texto (también porque no afectan al argumento de este artículo).

6 WITTGENSTEIN, Ludwig, op. cit., p. 43.

Véase, entre otros: JACKSON, Richard et al., Terrorism:A Critical Introduction, Palgrave Macmillan, Nueva York, 20I I; JACKSON, Richard, et al., Critical Terrorism Studies:A New Research Agenda, Routledge, London, 2009.
} 
de violencia, barbaridad y locura, pero cuyo significado preciso aún no está definido. Es, por lo tanto, una etiqueta lingüística cuya aplicación a un determinado tipo de violencia tiene unas consecuencias políticas muy específicas ${ }^{8}$.

Esto por qué, y es aquí donde Carl Schmitt nos aporta un marco teórico desde el cual analizar el "terrorismo", aunque los detalles del tipo de violencia que esta palabra debería indicar no están claros, el elemento fundacional de su uso es "la designación del enemigo". Esto se debe al hecho de que, a través de las características que conlleva la misma palabra, como la de locura, barbarismo e irracionalidad, ésta se utiliza políticamente para llevar a cabo la conversión del "enemigo" en lo que Schmitt define como al "enemigo absoluto"10. Consecuentemente, el término se usa para indicar un tipo de violencia política que tiene unas características específicasideológicas más que "físicas": el hecho de representar una amenaza a la identidad, la forma y la legitimidad de quién lleva a cabo el proceso de etiquetación. Es por esta razón que este tipo de violencia, junto con sus perpetradores, son etiquetados como "terrorismo": a través de estos matices de locura, irracionalidad y barbaridad se lleva a cabo una deslegitimación y una despolitización de esta violencia" que, si bien pertenece al terreno de lo político, se relega al campo de lo civilizatorio, de lo moral y de lo teológico.

Nuestra crítica a las teorías dominantes en la teoría política, en Relaciones Internacionales, por no mencionar la divulgación simplificada en los media y en los discursos políticos occidentales, es que la idea de "terrorismo" es una concepción lingüística que construye a un enemigo - no que lo crea-, sino que lo identifica al mismo tiempo que lo determina, confiriéndole una forma y asignándole unas características específicas debido al pesado bagaje lingüístico-semántico con el que carga el mismo término. En este sentido, este enemigo es "el" enemigo absoluto o, como diría Schmitt, es la negación óntica de lo propio. La absolutidad del enemigo se produce al desplazar, en el y a través del discurso occidental, el conflicto del terreno político - de las diferencias y antagonismos de los que persiguen y se afrontan - (I) al terreno civilizatorio ("terrorismo" como barbarie, de bávaros, de hordas bárbaras incultas y crueles en su sentido clásico y riguroso que como se definió en la Grecia clásica) que en realidad no es más que la secularización, quizás aparente, de la dicotomía cristianos/páganos que justifico la conquista de América en el siglo $\mathrm{XVI}{ }^{12}$; y/o (2) al terreno teológico, identificando "terrorismo" con el MAL ${ }^{13}$ —el terrorismo es el Mal_, el Mal como una enfermedad a erradicar, el Mal/Evil en su sentido más ontológicamente profundo ${ }^{14}$.

\footnotetext{
8 MARTINI,Alice, “Terrorismo: un enfoque crítico”, Relaciones Internacionales, vol. 28, 2015, p. I9I-199.

HÜLSSE, Rainer y SPENCER,Alexander, “The Metaphor of Terror:Terrorism Studies and the Constructivist Turn”, Security Dialogue, vol. 39, n. ${ }^{\circ}$ 6 (2008), pp. 57I-592.

10 SCHMITT, Carl, The Concept of the Political. Expanded Edition. The University of Chicago Press, Chicago, 2007.

" JACKSON, Richard et al., Terrorism., op. cit.

12 McGRANE, Bernard, Beyond Anthropology. Society and the Other, Columbia University Press, Nueva York, 1989.

${ }^{13}$ Las mayúsculas son a propósito.

${ }^{14}$ Se podrían poner ejemplos, ambos de procesos de descolonización -más el primero que el segundo- donde cabía una negociación en términos políticos, pues no había grandes diferencias civilizatorias o religiosas con el, por entonces laico, Frente de Liberación Nacional argelino o el Irish Republican Army. Ambos realizaron, entre 1954 y 1962 en el caso de FLN, y entre 1972 y 1994 en el caso irlandés, campañas de atentados en las metrópolis.Ambos conflictos acabaron -después de años o décadas, pero acabaron- en unas negociaciones de Paz.Aunque había una brecha religiosa entre la población musulmana, los católicos y los protestantes que nutrían respectivamente al FLN, a la IRA y a los grupos armados protestantes del Ulster y a la élite británica, el lenguaje y vocabulario político y laico era compartido por los contendientes.
} 
Visto desde otro punto de vista podríamos decir que, siguiendo a Mavelli, a través de esta designación y caracterización en el hacer frente a la amenaza terrorista, se vuelven a confundir las categorías cuya separación siempre ha sido considerada el orgullo de la modernidad: el noumenal y lo fenoménico ${ }^{15}$.En este sentido, lo que el discurso occidental hace es construir un "conocimiento" sobre el "terrorismo islámico radical". Éste vuelve a combinar, sin posibilidad de discriminación, los que Mavelli denomina como "posicionamientos de conocimiento" (claims of knowledge), más abiertos al escepticismo y más abiertos a la negociación - y que, por esta razón deberían ser la forma que tome cualquier confrontación dentro de este campo- con los "posicionamientos de fe" (claims of faith), de naturaleza dogmática, absoluta e innegociable — porque basados/creados por una única verdad superior- $y$, que por esta razón pueden dar lugar a la Violencia ${ }^{16}$.

\section{La violencia como constitutiva de la práctica política}

Lo político, dice Schmitt, no describe una sustancia propia sino la intensidad de una asociación - desasociación de los seres humanos cuyos motivos pueden ser religiosos, nacionales (en un sentido cultural o ético), económicos o de otro tipo. Como remarca el autor, no existe una "esencia" del fenómeno político; sin embargo, su naturaleza se puede descubrir cuando cierta antítesis (o conflicto) adquiere extrema intensidad". Hay una posibilidad "siempre presente"18 de que emerja un conflicto, un combate o una guerra. El término enemigo, al igual que guerra y combate, "requieren a la posibilidad real de exterminio físico"19. En este sentido, la guerra aparece así como el caso límite que define lo político y constituye el estado de excepción que llama a la decisión soberana.

Sin embargo, es dentro de esta concepción teórica que se entiende la famosa reformulación de Foucault de la aún más famosa cita de Clausewitz "La guerra es la continuación de la política por otros medios"20. Efectivamente, en su reinterpretación - "la política es la continuación de la guerra por otros medios"- Foucault hace hincapié en el carácter conflictivo de la política y de las relaciones sociales mismas que se articulan en formato de "guerra" $y$, sucesivamente, se plasman en la política. Esto se debe al hecho de que en la política se enfrentan los diferentes puntos de vista que componen el mundo, en una lucha para imponerse, por hacer prevalecer sus propios discursos, narrativas, valores e intereses ${ }^{21}$. El papel del poder político podría describirse, a lo Foucault, como reinscripción perpetua de la correlación de fuerzas por medio de una especie de guerra silenciosa que se reinscribe en las instituciones, en las desigualdades, $y$ en el lenguaje.

En esta línea, se puede argumentar que la violencia es constitutiva de la práctica política en diferentes maneras. (I) En la medida que ésta es la búsqueda o el uso del poder. Sobre el porqué de tal búsqueda o de tal centralidad del poder en la vida de los humanos las voces difieren: desde el animus domini presente en el ser humano hasta el poder para lograr y sustentar las formas de

\footnotetext{
15 MAVELLI, Luca, “Security and secularization in International Relations”, European Journal of International Relations, vol. I8, $\mathrm{n}^{\circ} \mathrm{I}, \mathrm{p} . \mathrm{I8I}$.

16 MAVELLI, Luca, “Security and secularization...”, op. cit., p. I8I.

17 SCHMITT, Carl, The Concept of the Political, op. cit., p. 184

18 SCHMITT, Carl, The Concept of the Political, op. cit., p. 184

19 SCHMITT, Carl, The Concept of the Political, op. cit., p. 184

20 Más específicamente, “La guerra no es más que la continuación de la política del Estado por otros medio”, frase que se encuentra en el De la Guerra de Carl von Clausewitz.

21 FOUCAULT, Michel, Society must be defended, Penguin, Londres, 1975.
} 
vida, las visiones de lo Bueno, que cada ser humano o cada comunidad tenga. Obviamente no todas las formas de poder son o no son calificadas como, violentas. Por ejemplo, Bertrand Russell en su libro Power se refiere al poder político militar, al poder económico y al poder sobre la opinión ${ }^{22}$. Este es el esquema que recoge E. H. Carr en The Twenty Years' Crisis ${ }^{23}$. Morgenthau incluye el prestigio (de una nación o de un estado) como una de las formas de poder. Bourdieu nos regaló el concepto de poder/capital simbólico. Inspirados por Steven Lukes ${ }^{24}$ podríamos hablar del poder como palanca (con el que se obliga a otros a moverse según nuestros deseos), como marco (que cerca y delimita las posibilidades de los dialogantes y del diálogo mismo) y como vocabulario, en el sentido de que - “los límites de mi lenguaje son/cumplen la función de ser los límites de mi mundo"25 - y, por tanto, quienes proporcionan o imponen su vocabulario, son los que acotan el mundo en el que transcurre la acción humana ${ }^{26}$.

La violencia es constructora de identidad (2) y fundadora de derecho y fundación de derecho equivale a fundación de poder" ${ }^{27}$. La violencia que convierte al otro en enemigo confiere estabilidad y firmeza al yo y al nosotros. La contraposición "amigo/enemigo" es una "realidad óntica" ${ }^{28}$, es decir, una distinción existencial. Para Schmitt no hay una justificación normativa posible -en ninguno de los sentidos, ni el de norma ética, ni el de norma jurídica- sino sólo existencial ${ }^{29}$. Las normas fundan la "situación normal" lo político, llevado a su extremo como Schmitt, es una situación crítica totalmente anormal en las que las normas ya no rigen. El concepto de lo político de Schmitt se asemeja al Dasein heideggeriano: es una forma del ser-ahí (Daseinform) ${ }^{30}$. Violencia, soberanía, y decisión son, para Schmitt, términos existenciales. Y esta herencia permea en, por ejemplo, Morgenthau, al que Raymond Aron calificó de existencialista avant la lettre.

Y porque (3) la violencia es fundadora de la juridicidad estatal ${ }^{31}$. Walter Benjamin sentenciaba que "fundar el derecho es fundar el poder, y es, por ende, un acto de manifestación inmediata de la violencia" 32 . El autor argumentaba que hay "un acto de violencia en la fundación de la ley"33;"todas las formas de violencia fundan derecho" y que "la primera función de la violencia es fundadora de derecho, y esta última, conservadora de derecho" ${ }^{34}$. Hasta Freud había defendido que "la civilización está construida sobre un crimen cometido en común"35; mientras que Tilly sostenía que la construcción estatal se parece al guerrear, al crimen organizado (y describía el

\footnotetext{
22 RUSSELL, Bertrand, Power, Unwin Books, Londres, 1975.

${ }^{23}$ CARR, Edward H., The Twenty Years' Crisis: 1919-1939:An Introduction to the Study of International Relations, Harper and Row, Nueva York, 1939.

${ }^{24}$ LUKES, Steven, Power. A Radical View, Palgrave Macmillan, Nueva York, 2000

25 WITTGENSTEIN, Ludwig, Tractatus ..., op. cit.

${ }^{26}$ Cabría extenderse sobre modelos más sofisticados del poder social., como el modelo IEMP de Michael Mann (The sources of social power, Vol. I, Cambridge University Press, Cambridge, 1986, pp. I-33), pero eso sería otro trabajo distinto.

${ }^{27}$ BENJAMIN, Walter, Para una crítica de la violencia y otros ensayos, lluminaciones IV, Madrid, Taurus, I998, p. 40

${ }^{28}$ SCHMITT, Carl, El Concepto..., op. cit.

29 Ibídem, p. 75

30 HAN, Byung-Chul, Topología de la violencia, Herder, Barcelona, 2016, p. 68.

31 Así empieza el cap. I de Grüner. En GRÜNER, Eduardo, Las formas de la espada, Ediciones Colihue, Buenos Aires, I997, p. 3 I.

32 BENJAMIN, Walter, Para una crítica, op. cit., p. 40.

33 GRÜNER, Eduardo, Las formas..., op. cit., p. 32.

34 Ibídem, pp. 29 y 30

35 FREUD, Sigmund, Tótem y tabú, citado por Grüner, Las formas..., op. cit. P. 31
} 
estado como gang mafioso violento) ${ }^{36}$. Ésta sería también la esencia — violenta- de la decisión fundante de Carl Schmitt —la decisión soberana- ${ }^{37}$. Pues no es posible decidir "científicamente en caso de conflicto sobre fines últimos" 38 y la autoridad soberana, lo Hobbes, se convierte así en la fuente de toda decisión moral y política ya fuera el presidente de la República de Weimar o el Partido Bolchevique una vez en poder ${ }^{39}$; etc.

El estado moderno, el Leviatán —ese hombre o asamblea de hombres que reitera Hobbeses "al mismo tiempo el detentador de la Palabra que hace la Ley —el Gran Definidor lo llamaba Hobbes-y de la espada pública (un concepto extraído de S.Agustín)"40. Es el gran adjetivador y el gran defensor de sí mismo hasta el punto queWeber lo define como el que tiene el monopolio de la violencia legítima. En palabras de Eduardo Grüner "[...] salvar el Derecho mismo significa aquí salvaguardar el derecho a la utilización 'de la violencia históricamente reconocida' y establecida, 'normalizada' como poder político: poder político que no existe si no es para esa 'normalización' del uso de la violencia"4l.

Es más, el estado moderno y el contrato son posibles por la "renegación de la violencia constitutiva de lo político"42. Las asambleas, hoy parlamentos, donde se expresaba la voluntad de los súbditos nacen, según Otto Hintze ${ }^{43}$, como fruto de las guerras, en concreto de las guerras de religión en Europa. Esta tesis - podríamos decir que casi una premisa fundadora de la moderna Sociología histórica - es desarrollada por Tilly ${ }^{44}$ y otros de sus colegas: todo contrato es, entre otras cosas, la expresión de una correlación de fuerzas donde siempre hay vencedores y vencidos ${ }^{45}$. Pero como diría Nietzsche y repetiría Foucault, lo que nos parece obvio está basado en mentiras y actos de forma que han pasado al ámbito del olvido ${ }^{46}$.

Aunque tampoco (4) toda política o toda acción política es, en sí misma, violenta: la mayoría no lo son. Nuestra gestión de los conflictos no recurre habitualmente a la violencia directa. Incluso en las democracias parlamentarias se puede llegar al gobierno por vía electoral ${ }^{47}$ (si eso es llegar al poder en sentido schmittiano o no, es algo a dilucidar) y obtener enormes cuotas de poder de

${ }^{36}$ TILLY, Charles, "War-making and state-making as organized crime", en EVANS, Peter, RUESDESCHEMEYER, Dietrich y SKOCPOL, Theda (eds.), Bringing the State Back In, Cambridge University Press, Cambridge, 1985.

${ }^{37}$ Sobre todo, tal y como aparece en SCHMITT, Carl, La Dictadura, Alianza Editorial, Madrid, 2013 [1928]

${ }^{38}$ NEGRETTO, Gabriel, L., “El Concepto de Decisionismo en Carl Schmitt: El Poder Negativo de la Excepción”, Sociedad, vol. 4, 1994, pp. 66 89.

${ }^{39}$ Ibídem, p. 3.

${ }^{40}$ GRÜNER, Eduardo, Las formas..., op. cit., p. 33.

${ }^{41}$ Ibídem, p. 35.

$42 \mathrm{lbid}$, p. 36.

${ }^{43}$ HINTZE, Otto, "La configuración de los estados y el desarrollo constitucional, Análisis histórico-político" (1902), reproducido en Relaciones Internacionales, núm. I, 2005, pp. I-19. http://www.relacionesinternacionales.info/ojs/article/view/5.html

${ }^{44}$ TILLY, Charles, “War-making and state-making...”, op. cit, y TILLY, Charles, Coercion, Capital and European States, ad 990-1990, Basil Blackwell, Cambridge, 1990.

45 GRÜNER, Eduardo, Las formas..., op. cit., p. 46.

${ }^{46}$ FOUCAULT, Michel, Nietzsche, la genealogía y la historia, Pre-textos, Valencia, 1992.

${ }^{47}$ No para generaciones futuras si estas líneas salen a luz y alguien las lee. Los partidos que Marx inspiraba y a los que Engels ayudó a formar eran los partidos socialdemócratas. Solo a partir de 1921 los seguidores de los Bolcheviques (ellos mismos "la mayoría" del Partido Obrero Socialdemócrata Ruso) empezaron a construir partidos denominados comunistas que formaban parte de la Tercera Internacional. Ya en Engels en la "Introducción" a la edición de 1895 de La lucha de clases en Francia (1850), veía claro la posibilidad de llegar a poder a través de elecciones parlamentarias. 
cambio/conservación. Pero el marco en el que se da esa acción política no violenta -el ágora donde los ciudadanos discuten sesudamente como soñaba Hannah Arendt - sí es un producto de la violencia y enmascara su potencial de violencia tras reglas, o reglamentos, sí establece un marco de violencia potencial de lo discutible, pensable $y$, desde luego, lo posible; $y$ sí permite o impone un vocabulario que determina lo que conocemos y lo que siquiera podemos imaginar.

\section{El conflicto como elemento ontológico y la lucha en contra del "terrorismo"}

El conflicto tiene un estatus ontológico dentro de nuestra realidad puesto que es un elemento inherente a todas las relaciones sociales - y, por lo tanto, a todas las relaciones políticas $-{ }^{48}$. Éste es, en consecuencia, un elemento a gestionar y no un problema a eliminar — siendo su erradicación imposible-49. Por lo tanto, si se considera la centralidad que el elemento conflictivo tiene en nuestra realidad, se llega a entender por qué el proceso de moralización del enfrentamiento de diferentes cosmovisiones presentes en el mundo es no solamente equivocado desde un punto de vista ético, puesto que cada postura debería poder gozar del mismo reconocimiento de una cierta legitimidad, sino también peligroso puesto que llega a convertir en el mal absoluto choques de intereses que podrían ser ajustados de otra manera.Y es que el mundo no es un lugar pacífico en el que se pueda pretender homogeneizar todas las diferencias bajo un mismo umbral de valores e ideas, sino que éste se compone de una pluralidad de concepciones de la ética -muy a menudo, conflictivas entre ellas- que chocan entre sí. Sin embargo, este conflicto no se traduce automáticamente en violento: es aquí que la política no debería transformar estos diferentes posicionamientos en los que hemos llamado "posicionamientos de fe", posturas no negociables que acaban enfrentándose violentamente, sino - a través de la diplomacia y de la política mismaajustar esta colisión entre diferentes intereses y convertirlo en un choque de "posicionamientos de conocimiento" 50 .

Efectivamente, un conflicto entre el Bien y el Mal, entre Civilización y Barbarie - como se presenta el conflicto entre mundo "occidental" y el "terrorismo islámico"- — sólo se puede resolver mediante la pareja de dispositivos conversión o conquista ${ }^{51}$, y casi es mejor la segunda opción.Ambos dispositivos presuponen y son violencia y poder y tienen lugar dentro de un juego asimétrico: alguien convierte o conquista a alguien, quién produce el discurso se pone en una posición hegemónica sobre quién lo recibe. Sin embargo, existen (histórica y teoréticamente) situaciones donde sólo la conquista entendida como aniquilación es una opción válida. En esta línea, Schmitt llegó a argumentar que con el Mal no se puede negociar, no se puede "ni mirarlo", aunque, en un paso previo a esto, también se refiere a esta "conversión o conquista" 52 . ¿Pero la conversión no estaría reservada sólo a los enemigos que están a nuestro mismo nivel o que se someten y aceptan integrar dentro de sí -a su manera mestiza - la visión del mundo de los conquistadores? ¿Cómo convertimos algo que no podemos tocar/mirar/hablar? ¿Y dónde cabe la aniquilación/eliminación dentro de esto? Las preguntas no son baladíes y volveremos sobre ellas.

\footnotetext{
${ }^{48}$ MOUFFE, Chantal, Agonistics. Thinking the World Politically, Verso, Londres, 2013. MOUFFE, Chantal, On the Political. Thinking in Action, Routledge, Nueva York, 2005.

${ }^{49}$ Ibidem.

50 MAVELLI, Luca, “Security and secularization...," op. cit., p. I8I.

5I TODOROV,Tzvetan, La conquista de América. El problema del otro, México: Siglo XXI, 1989.

52 SCHMITT, Carl, The Concept of the Political, op. cit, p. 184
} 
La conversión implica una situación en la que alguien impone el marco, el vocabulario, y es Su Palabra. En el caso que nos ocupa las pautas van más por el camino de la conquista/exterminio que por la persuasión de la Palabra. Ya en los primeros 80 del siglo pasado un historiador norteamericano, Arthur M. Schlesinger, seguidor de Hans Morgenthau, argüía (sobre la Guerra Fría):

“La moralización de la política exterior crea problemas aún más graves. En verdad, razones morales cínicamente explotadas pueden hacer al mundo menos daños que razones morales fervientemente creídas. La compulsión a convertir conflictos en intereses entre conflictos entre el bien y el mal socaba la diplomacia. Pues la diplomacia es, sobre todo, ajuste de intereses en conflicto. La moralización de cambia las relaciones internacionales del modo político, que es condicional, al modo ideológico, que es incondicional" ${ }^{53}$.

Volviendo a nuestro hilo principal, como hemos señalado, esta lucha se traslada, sobre todo en algunos casos, al campo de la moral, en el cual es más fácil deslegitimar y despolitizar al enemigo, puesto que estamos en un ámbito que la modernidad occidental ha separado de la política (como desarrollaremos más en detalle más abajo). Este proceso se lleva a cabo con, por ejemplo, el "terrorismo", con el cual la negociación de los distintos objetivos políticos es imposible (o mejor, se presenta como imposible) porque éste se construye no como una manera de hacer política - aunque violenta - sino como la expresión más profunda de la maldad o del salvajismo. Claramente, esto conlleva que cualquier mensaje quiera transmitir este tipo de violencia política pueda repudiarse.Y es que el "terrorismo", narrado a través este registro moral, es un MAL tan grande que en el hacer frente a ello no puede caber otra opción que su más completa aniquilación. Esto se debe al hecho de que no se puede dialogar con el MAL porque nunca puede haberse ningún tipo de entendimiento entre éste y el bien - los que luchan en contra del "terrorismo".

Este proceso tiene muchas consecuencias. La primera, como hemos mencionado, es el rechazar y renegar el mensaje que este tipo de violencia quiere lanzar. Un proceso peligroso puesto que, como nos recuerda Chantal Mouffe, el renegar mensajes políticos - aunque se expresen de forma violenta - lleva a más violencia ${ }^{54}$. La segunda es que este proceso permite llevar a cabo como respuesta una violencia que ontológicamente no es diferente. Esta despolitización y moralización del "terrorismo" tiene otra consecuencia que se traduce en la posibilidad de luchar en contra del "terrorismo" fuera del campo de lo político y, por lo tanto, de lo legal. Esto se debe al hecho de que la lucha contra el MAL y su erradicación se presentan como tan importantes y urgentes que en contra de ello cualquier medio vale. Si el objeto que se tiene que eliminar está situado fuera de lo político y de lo legal, así pueden estarlo los medios con los que se le quiere aniquilar. Efectivamente, como decía Schmitt, "contra el partisano se lucha con medios partisanos" 55 . Se agudiza aún más lo que es un conflicto asimétrico: en este sentido, si el partisano recurre a medios ilegales por el no poder utilizar otros legales y que requieren más recursos, asimismo quién lucha contra el partisano puede hacer uso de medios ilegales - o normalizar medios ilegales - en larga escala. Las consecuencias se podrían resumir en todo vale para la erradicación de este MAL/

\footnotetext{
53 SCHLESINGER, Arthur M., Los ciclos de la historia americana, Alianza Editorial, Madrid, I988, p. 90.

${ }^{54}$ MOUFFE, Chantal, Agonistics..., op. cit.. MOUFFE, Chantal, On the Political, op. cit.

55 SCHMITT, Carl, The Theory of the Partisan. A Commentary/Remark on the Concept of the Political, Michigan State University Press: East Lansing, 2004, p. 25.
} 
BARBARIE: Guantánamo, drones sobre poblaciones civiles (legitimados por la lógica del "daño colateral" $\left.{ }^{56}\right)$, asesinatos como el de bin Laden, cárceles secretas de la CIA fuera del territorio estadounidense, recortes generalizados de las libertades públicas en los países que conforman el frente "anti-terrorismo" (por ejemplo, el Patriot Act estadounidense).

\section{Reflexiones sobre la "civilización"}

Hagamos una pausa desde los argumentos sobre la violencia para hablar de "civilizaciones" "occidentales". La idea (discursiva y operativa) de Europa empezó a surgir tras el descubrimiento de América. Sostienen los historiadores de la Edad Moderna Europea que la misma idea de Europa surge como consecuencia de la entrada en la conciencia colectiva europea de la existencia de ese continente (con el que la visión clásica, la de Tolomeo no contaba) ${ }^{57}$. Este proceso parece que se reproduce en todos los grupos humanos. Empezaba a haber conciencia de Nosotros cuando se toma conciencia de la existencia de unos Ellos. De hecho, este es el fundamento normativo del estado-nación: la existencia de un nosotros — ciudadanos, formas de vida, etc. —, de un inside frente a los otros, un outside ${ }^{58}$. Es un argumento que se puede llevar aún más allá y argumentar, como ya se ha dicho antes, que en ese binomio un elemento no puede existir sin su contrario, como nuestra idea del bien no podría existir sin el mal, la paz sin la guerra y la civilización sin la barbarie. Así el inside no podría existir sin outside, y la categoría de ciudadanos no tendría sentido sin una de "no ciudadanos".

Asimismo, la tradición europea es esencialmente binaria en sus categorías dentro/fuera, cristiano/pagano, civilizado/salvaje, bien/mal, justo/injusto, etc. En este sentido el discurso sobre el encuentro de los europeos con los americanos se basaba en esta dicotomía cristiano/pagano. La conquista castellana de América dio lugar a acontecimientos dramáticos, chuscos o de caldo filosófico: las encomiendas el “Requerimiento", La Discusión deValladolid, etc. ${ }^{59}$.Para el liberalismo el enemigo, el bárbaro, alguien que puede ser entendido, caracterizado y definido solo en su relación con una civilización y con el hecho de él existe fuera de ella. No puede haber bárbaros si no existe una isla de civilización en algún lugar, si el bárbaro no vive fuera de ella y si no la combate $^{60}$. La conciencia de los protegidos se desarrolla cuando esa protección tiene fisuras y la amenaza se cuela entre ellas. Como diría Žižek, hay incluidos y excluidos del bienestar del capitalismo global ${ }^{61}$ y su auto conciencia viene determinada por su pertenencia a uno de los grupos que es visible y reconocible por la existencia del otro. En este mismo sentido -enmarcado en que Schmitt siempre trabaja sobre casos extremos, excepcionales - este autor platea que la comunidad se hace política en el momento que siente amenazada su existencia por un enemigo y

\footnotetext{
56 Hay que recordar que, por ejemplo, en los últimos años, EE.UU. más veces reconoció haber matado civiles con sus drones en el marco de la lucha contra el terrorismo. En 2016, reconoció hasta 116 muertes de "no combatientes" en sus ataques selectivos en Pakistán, Yemen, Somalia y Libia desde que el presidente Barack Obama asumiera su cargo en 2009. En "Estados Unidos reconoce posibles bajas civiles en un bombardeo de la coalición en Siria”, en eldiario.es, 29.07.2016. [visitado el 24.08.2018]. Disponible en http://www.eldiario.es/politica/EEUUreconoce-bombardeo-coalicion-Siria 0 542445800.htm

57 ELIOT, John, Imperios del Mundo Atlántico. España y Gran Bretaña en América (1942-I830), Santillana Ediciones Generales, S.L., Madrid, 2006. ELLIOTT, John, The Old Word and the New, Cambridge University Press, Cambridge, 2003.

58 WALKER, R. J.B., Inside/outside. International relations as political theory, Cambridge University Press, Cambridge, 1993.

59 TODOROV,Tzvetan, La conquista de América..., op. cit.

60 Cita de Michel Foucault en PROZOROV, Sergei, “Liberal Enmity: The Figure of the Foe in the Political Ontology of Liberalism”, Millennium: Journal of International Studies, vol. 35, n. I, 2006, p. 95.

61 ŽlŽEK, Slavoj, La nueva lucha de clases. Los refugiados y el terror, Anagrama, Barcelona, 2016.
} 
necesita afirmarse a sí misma frente a éste, es decir, en el momento de la guerra ${ }^{62}$. La posibilidad real de la violencia constituye la esencia de lo político63.

La "banalidad del bien" ${ }^{64}$, lo que Nicolás Casullo, remedando a Hannah Aredt, ha llamado a una banalidad de almas bellas y buenas conciencias, pero de mala fe, olvida, o — de nuevodesconoce prolijamente que en nuestra sociedad no hay Bien que del Mal no venga. $\mathrm{O}$, como argumentaba Benjamin, que no hay documento de civilización que no sea, simultáneamente, un documento de barbarie ${ }^{65}$.

El discurso occidental está cómodamente situado en el terreno de una lectura de la Ilustración y su marco epistémico, vulgarizados, simplificados y ahistóricos, eurocéntricos, y de la Historia como progreso, de la violencia como excepción, del conflicto como siempre resoluble (si hay buena voluntad, y a los occidentales se les supone) y que, en última instancia, existe una armonía de intereses, que se dará en el curso de la historia, ayudada por la ciencia y la técnica - como critica Hans Morgenthau en su Scientific vs. Power Politics ${ }^{66}$ - y gracias a la mano invisible de Adam Smith ${ }^{67}$, la astucia de la naturaleza kantiana o el cinismo de la virtud pública de los vicios privados de la fábula de las abejas de Bernard de Mandeville ${ }^{68}$.

Como veremos más abajo, se olvida las aportaciones de la misma teoría política occidental desde Maquiavelo, Hobbes hasta Mouffe —-pasando por Nietzsche, Otto Hintze, Weber, Schmitt, Benjamin, Morgenthau, Carr, Foucault, Bourdieu en sus Meditaciones Pascalianas ${ }^{69}$, Derridá en su Fuerza de ley. El "fundamento " místico de la autoridad" ${ }^{70}$, etc. - . Ninguno de estos autores se hizo la más mínima ilusión sobre la posibilidad de combatir -incluso comprender- los conflictos de poder sobre la base de las buenas intenciones, la buena voluntad o la disposición al diálogo de los sujetos cuyos intereses (materiales o simbólicos) estaban comprometidos en el conflicto. Ni las bellas almas de un Rousseau o Kant llegaron tan lejos en su optimismo voluntarista ${ }^{71}$.

Negarse a ver y a entender, hasta donde sea posible con nuestras actuales herramientas teóricas, la violencia como constitutiva de lo político y su carácter de estrategia de dominio según Nietzsche ${ }^{72}$, puede tranquilizar nuestras conciencias que buscan la identidad de verdad y liberación -o bondad-. Sin embargo, no nos hará avanzar en la erradicación de ese dominio ${ }^{73}$.

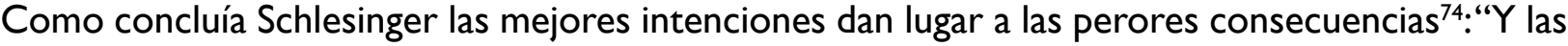

62 HAN, Byung-Chul, Topología de ..., op. cit., p. 65

${ }^{63}$ SCHMITT, Carl, The concept of the..., op. cit., p. 65

${ }^{64}$ CASULLO, Nicolás, “La banalidad del bien”, en el Rodaballo, Revista de cultura y política, n. I, I994, p. 16.

65 BENJAMIN, Walter, Para una crítica de..., op. cit.

66 MORGENTHAU, Hans, Scientific man vs Power politics, Latimer House Limited, Londres, 1947.

${ }^{67}$ SMITH, Adam, Una investigación sobre la naturaleza y causas de la riqueza de las naciones, W. Strahan \& T. Cadell, Londres, I776.

68 MANDEVILLE, Bernard,“La fábula de las abejas: o, vicios privados, beneficios públicos” en Roles sexuales: la mujer en la historia y la cultura, María José Rodríguez, E. Hidalgo y C.G.Wagner (eds), Ediciones clásicas, Madrid, I994, pp. I9I-I 2 I.

69 BOURDIEU, Pierre, Meditaciones Pascalianas, Anagrama, Barcelona, 2006.

70 DERRIDA, Jacques, Fuerza de ley. El fundamento místico de la autoridad. Tecnos, Madrid, 2002.

7I GRÜNER, Eduardo, Las formas de..., op. cit., p. 28.

72 NIETZSCHE, Friedrich, La voluntad de poder, Biblioteca Edaf, Madrid, 20I I [ I90I].

73 GRÜNER, Eduardo, Las formas de..., op. cit., p. 29.

${ }^{74}$ SCHLESINGER, Arthur M, Los ciclos de la historia..., op. cit., p. 90 
almas bellas que se sienten superiores a mundo corrupto mientras en secreto participan en él: necesitan un mundo corrupto, pues es el único terreno en el que pueden ejercer su superioridad moral"75.

\section{La civilización, la secularización y los conceptos de lo político}

Los conceptos políticos modernos son conceptos teológicos secularizados ${ }^{76}$, y comparten el mismo marco epistémico moderno. Según una idea de Schmitt ${ }^{77}$, sucesivamente desarrollada por Koselleck, sólo cambiaron la gramática, el vocabulario político: la autoridad del Rey que es donación divina se transmuta en la autoridad del estado que mana de la soberanía nacional o popular según las versiones, etc. Koselleck defendía que, en el cristianismo, una “Imagen trascendente que, como imagen del Otro absoluto, hace de Tercero garante de que el lazo entre los sujetos no sea puramente especular: Dios —y luego el Estado cuando se produzca la separación entre la teología y el derecho- es el espejo transcendente (de los sujetos)" ${ }^{\prime 78}$.

En realidad, esta separación (con mucho de superficial) de la vida social entre lo público y lo privado, entre política, economía y relaciones sociales, entre creencias teológicas o metafísicas y posturas políticas dan lugar a subjetividades de diferentes orígenes. Sin embargo, también "homogenizan" subjetividades diferentes en los mismos patrones. Por ejemplo, los musulmanes tienen que adaptarse, en la mayoría de los casos y cada vez más, a la división entre público y religioso, si viven en estados "laicos"79 $y$, en cualquier caso, si sus estados de residencia han asumido la cultura de la estatalidad dejada en herencia por el colonialismo y reforzada por la actual estructura del sistema de estados.

Éste, como ahora veremos, "aristotelismo" influye a través del cristianismo tomista en la concepción de lo político como un ámbito propio y separado y de la práctica política. Arendt dixit, como la actividad más excelsa de lo humano. Las lecciones de la crisis generalizada del siglo XVII — Guerra de los Treinta años, guerra civil en Inglaterra, desgarramientos de la Corona española, la física de Newton, el pensamiento de Descartes, etc.- y la aparición, fomentada por los estados ${ }^{80}$, de relaciones de producción protocapitalistas y capitalistas dan origen a la idea del estado/sociedad como contrato laicizando las formas de sujeción política ${ }^{81}$. La emergencia de la modernidad no fue un proceso intelectual autónomo, al margen de la coyuntura histórica, de la correlación de fuerzas de la base materiales e ideacional social, económica y política ${ }^{82}$.

Hay toda larga y fructífera discusión sobre el fin de las Guerras de Religión trajo la secularización $\circ \mathrm{no}^{83}$. Se trata de diversas combinaciones de elementos y procesos históricos

\footnotetext{
75 ŽIŽEK, Slavoj, La nueva lucha de clases., op. cit, p. 14.

76 SCHMITT, Carl, Teología politica, Trotta, Madrid, 2009. De hecho, es la primera frase del tratado.

77 lbidem.

${ }^{78}$ Citado en IRANZO, Ángela, "Continuidades del factor religioso en la historia de las relaciones internacionales. Reflexiones en torno a la narrativa del 'resurgimiento de la religión' tras el II-S”, tesis doctoral defendida en la Universidad Autónoma de Madrid, p. I4I.

79 Recordemos aquí, por ejemplo, las polémicas sobre el burquini en Francia o las sobre las dietas sin cerdo en los colegios públicos de Dinamarca.

80 POLANYI, Karl, La gran transformación. Critica del liberalismo económico. La Piqueta, Madrid, 2007 [1947]

81 GRÜNER, Eduardo, Las formas de..., op. cit., p. 23

82 Ibídem, p. 17

${ }^{83}$ MAVELLI, Luca, “Security and secularization...", op. cit., pp. I8I a 187
} 
sobre la secularización de la política europea entre los príncipes constructores de estados y las diferencias dogmáticas, organizativas y prácticas dentro de la Res Publica cristiana, o sea entre la Reforma y la Contrarreforma. La emergencia del estado moderno y, por tanto, del concepto moderno del poder y de lo político, después de la Paz de Wesfalia, no dio como resultado la privatización y la irrelevancia de las creencias religiosas, sino la diferencia entre estado, iglesia y sociedad en un estado confesiona ${ }^{84}$. La tesis de Mavelli, siguiendo a C.M.Williams, es que "(hay que considerar que) la búsqueda moderna de la seguridad no ha sido un resultado de la Reforma y de puntos de vista distintos sobre la religión que se radicalizaron en violencia, sino el resultado de una más temprana crisis del escolasticismo. Es la emergencia de la imagen nominalista del mundo —un mundo caracterizado por el caos y sin una base de unidad - lo que marca el comienzo de la desaparición de Dios de los asuntos humanos [...] y, por tanto, puede ser considerado la irrupción de la secularización" ${ }^{85}$.

Los nominalistas, como Hobbes, se centran en la idea escolástico-aristotélica de ley natural y ley divina, que tan claramente aparece, por ejemplo, en Grocio, y la sustituyen por el estado de naturaleza, donde cada hombre es enemigo de los otros hombres, y la ley es la del Leviatán. En este sentido el famoso dictum de Schmitt de que los conceptos políticos modernos son conceptos teológicos secularizados deben entenderse que estos conceptos teológicos son los del pensamiento voluntarista-nominalista triunfante en la teología cristiana ${ }^{86}$.

Creemos, sin embargo, que, a pesar del debate historiográfico, se pueden avanzar dos postulados que no se discuten. En primer lugar, los estados que surgen dela Paz de Westfalia no son laicos ni a confesionales, sino que la religión del príncipe es la religión del estado; en segundo lugar, del culto religioso se va transitando al culto del Estado mismo, que pasa a ser central en la vida de los ciudadanos; el príncipe pasa a ser quién proporciona - y a quién hay que rogarel bienestar terreno y quién puede decidir sobre los castigos; $y$, en tercer lugar, que ya no se produjeron más guerras europeas interestatales por diferencias religiosas, sean éstas dogmáticas o de cualquier otro tipo ${ }^{87}$.

La Secularización es una categoría epistémica central para la forma en que Occidente entiende la modernidad y sobre la cual occidente ha basado su supuesta superioridad moral, su supuesto avance en la línea del progreso; es una forma de entender las relaciones — separaciónentre política y religión. Esta separación forma parte de imaginario social occidental, que no es monolítico geográficamente, que crea una subjetividad secular y da lugar a su sistema de poder/ conocimiento que construye al otro musulmán, por ejemplo, como negación del "idealizado self

\footnotetext{
${ }^{84}$ Ibídem, p. 182 nota 5.

${ }^{85}$ Y continúa "La búsqueda moderna de la seguridad [...] puede ser el resultado del proceso de secularización y no lo que hizo posible este proceso”, lbíd., p. 185.

86 "El Nominalismo es una visión de las propiedades [...] la idea de que no hay universales sólo particulares (por ejemplo, no hay una idea universal de la justicia sólo dimensiones discretas que, dependiendo del contexto, pueden representar la idea de justicia. Voluntarismo es una perspectiva sobre el poder de Dios donde éste es absoluto, no contenido y/o ordenado (ordained) [sic.]”. MILBANK, J. P. L, “Against biopolitics", Theory, Culture \& Society, 2008, 25 (7-8), p. 130.

87 Grüner sostiene una tesis parecida: la política (la dominación tal como la conocemos hoy “(encontraba) [...] en el cristianismo un fundamento [...] en la religión: un re-ligare de nuevo tipo entre los sujetos, en tanto estos ya no se deben a la polis (espacio de inclusión de los dioses) sino a una Idea transcendente”, GRÜNER, Eduardo, Las formas de..., op. cit. p. I 7.
} 
occidental secular (idealised Western secular self) ${ }^{88}$. Esto significa dos cosas: la primera, que Dios, la divina providencia o cualquier ser/voluntad ahistórica y ahumana no puede ser utilizada como causa motora (al estilo escolástico) o eficiente o como argumento explicativo de los fenómenos humanos y/o sociales y naturales, como causa o justificación de las visiones políticas que afectan a la comunidad o como elemento fundador de la ética y de los comportamientos a seguir en la sociedad; $y$, segunda, la religión, las creencias, o las omnivisiones del Bien a lo Rawls, caen dentro de la esfera de lo privado, no de lo público (el estado será, en principio, laico). Estas cuestiones se relegan a unos espacios - y momentos - específicos y éstos no tienen que -en principiointerferir con lo que es la vida pública dentro del estado. En definitiva, se elimina la idea de lo trascendente $\longrightarrow$ en términos de Rawls las ideas y/o creencias sobre el Bien absoluto-, de trascendencia del ámbito de lo público de la vida social y se puede considerar como norma central que dirige la vida estatal el sentido cívico, una ética secularizada que hace hincapié en un sentido moral vaciado de su contenido religioso y conlleva el "bien de la sociedad", lo que es mejor para el estado - y su supervivencia.

El concepto de secularización, en la distinción de esferas de la vida social y de lo perjudicial que puede suponer, no ya la imposición de unas sobre otras que justamente combate Michael Walzer ${ }^{89}$, sino su propia confusión y la difuminación de sus fronteras (que ya sabemos que son ficciones operativas pero que encauzan comportamientos) es una experiencia europea occidental. Su renovada fama, como el renovado interés en la academia por la de secularización, bien determina del contacto y el enfrentamiento con ese otro que niega tal separación. En ese combate Occidente, no abandona de palabra la separación de esferas, simplemente, constata una diferencia civilizatoria — peligrosa en extremo—y lo teologiza trasladándola más allá de lo humano, a lo teológico, al Mal. Hannah Arendt dibuja un ideal de dicho estado:

"(la) estilización (de Arendt) de la imagen de la polis griega como esencia última de lo política la conduce a dicotomías rígidas entre lo <público> y lo <privado>, entre lo <político> y lo <social>, entre el <Estado> y la <economía > que no se ajustan a la complejidad, los desgarramientos y las nuevas formas de opresión de las sociedades modernas" 90 .

El concepto de lo político en la modernidad occidental es secular, no cuenta con la divinidad, lo ahistórico y ahumano como sustento, causa o argumento. El concepto moderno de lo político se basa en dicotomías que distinguen esferas de la vida social: privado/público/estado/ sociedad civil, política/economía, lo político/lo social, etc. De hecho, la tesis de Michael Walzer para lograr una comunidad justa es que estas esferas nunca dominen o sobre-determinen unas a otras ${ }^{91}$; en el mismo sentido, pero con otra orientación, la política para Rawls es procedimental, que deja a un lado las concepciones sustantivas del Bien de los actores ${ }^{92}$. Esta distinción entre lo político y lo teológico está muy lejos de realizarse completamente en la práctica —ver cómo lo movimientos religiosos cristianos europeos influyen en la formulación del Estándar de

\footnotetext{
${ }^{88}$ MAVELLI, Luca, "Between Normalisation and Exception:The Securitisation of Islam and the Construction of the Secular Subject", Millenium: Journal of International Studies, vol. 4I, n² 2, 20I3, pp. I59-I8I. MAVELLI, L., op. cit., "Between normalization...” and exception, pp. I6I y I62.

${ }^{89}$ WALZER, Michael, Spheres of Justice. A defense of pluralism and equality. Basic Books, Nueva York, 1983.

${ }^{90}$ GRÜNER, Eduardo, Las formas de..., op. cit., p. 57.

91 WALZER, Michael, Spheres of ..., op. cit.

${ }^{92}$ RAWLS, John, Political Liberalism. Columbia University Press, Nueva York, 1993.
} 
civilización ${ }^{93}$ - Además, recordamos la sentencia de Schmitt sobre el origen teológico de los conceptos políticos modernos, y desde luego, como bien sabemos, hay muchas reminiscencias de lo teológico en la vida cotidiana pública: el dólar viene marcado por la sentencia "In GodWe trust"; el calendario de las fiestas en los países occidentales confunde fiestas nacionales y religiosas; o, hasta 1994, el presidente de Argentina tenía que ser católico por mandato constitucional ${ }^{94}$. Pero está claro que está secularización, esta división en esferas (a loWalzer) está firmemente asentada en el horizonte normativo occidental, en su discurso y en sus relatos sobre los conflictos. Esta secularización, que lo es, deja el campo abierto a una metafísica - que resuena teológica aun sin proponérselo- de conceptos como la mano invisible y, sobre todo, la astucia de la Naturaleza kantiana.

Pero sea en su versión realista -impulso al dominio, búsqueda de poder en el fondo como seguridad de lo propio, o la dialéctica de amigo/enemigo- o en la versión liberal de Arendt - en la polis, la política empieza donde acaba la violencia - la religión no está presente o por lo menos, no lo está abiertamente o sin disfrazarse y, de estarlo, no puede esgrimirse como razón, argumento o causa. Es decir, las dos corrientes filosófico-teóricas que influyen en la modernidad occidental en discursos y en sus relatos — la kantiana-habermasiana y la inspirada por Hobbes, Nietzsche,Weber, Schmitt y, hoy Mouffe, comparten la separación del ámbito lo político — propio de la esfera pública- y el de las creencias religiosas — recluido en la esfera de lo privado. Los discursos de los políticos y de los mass-media tienen resonancias, muy abrumadoramente, de la primera de estas corrientes.

Es más, en el imaginario social moderno, la entrada de la religión en la política, cuando abandona de lo privado y entra en lo público se convierte en "una potencial amenaza a la seguridad" 95 , no hay más que recordar la polémica sobre el velo en las escuelas en Francia. Para recordarnos la fuerza de la religión en la política, Mavelli cita a Pascal: “los hombres no hacen el mal tan completa y alegremente como cuando lo hacen desde convicciones religiosas" 96 . Como se menciona repetidamente en este trabajo la separación de esferas de la vida humana es esencial para la modernidad: desde el enemigo absoluto de Schmitt hasta el overlapping consensus de Rawls.

Volviendo a retomar nuestro hilo sobre violencia política,y sumándole estas consideraciones sobre civilización y secularización o no de lo político, argumentamos que el enfrentarse al "terrorismo islámico" sale de esta estructura dicotómica. El discurso que se produce vuelve a acercar las dos esferas para poder entremezclar lo que es político con lo que es moral - puesto que se empieza por la esfera política, característica de esta violencia- pero se acaba luchando en contra de ella en la esfera religiosa/moral/ética. Nuestra crítica al relato estándar del terrorismo es la construcción discursiva de un enemigo y su desplazamiento fuera del ámbito de lo político para situarlo en el ámbito de lo civilizatorio (barbarie) y, sobre todo, de lo ético-teológico (el Mal).

\footnotetext{
93 PEÑAS ESTEBAN, Francisco Javier, "Estándard de civilización: las historias de las relaciones internacionales", Revista Jurídica Universidad Autónoma de Madrid, n. I, 1999.

94 Ya no se reclama un católico para presidir la Argentina. Incluso se incluyó en 1994 un artículo que permite tomarle juramento al presidente respetando sus creencias religiosas.

95 MAVELLI, Luca, “Security and secularization...", op. cit, p. I78.

96 Ibídem.
} 
Sin embargo, estas organizaciones "terroristas islámicas" también sitúan el conflicto, con sus acciones y sus víctimas en el ámbito de lo civilizatorio (rechazo a la modernidad occidental) y de lo teológico (la comunidad regida por la ley de Dios). Es, en este sentido, que argumentamos que el choque con la violencia política del Islam radical va más allá de lo que ha sido el choque con una violencia terrorista de los movimientos de liberación de los años 70 ○ el IRA ○ las FARC y, por los elementos que hemos venido mencionando hasta aquí, ya se puede definir, aunque nos pese, como un choque civilizatorio. Pues lo que se enfrentan son dos proyectos políticos y de organización social especulares puesto que, como hemos dicho antes, uno de los dos divide y considera irreconciliables entre ellas estas esferas fuera de esta dicotomía mientras que el segundo no puede entender la primera sin la otra, puesto que, en esta visión, las dos se retroalimentan y coexisten. En esta luz, se puede entender por qué, dejando al lado el uso de la violencia, el proyecto político occidental es incompatible con el proyecto teocrático que este tipo de terrorismo persigue, aunque de diferentes formas y a través de un uso diferente de la violencia.

Efectivamente, el tipo de modelo político que tanto al-Qaeda o el Daesh y sus relativas franquicias quieren lograr imponer - y que en algunos casos imponen, como pasa con el Daesh en los territorios que controla en Siria e Iraq - es el de un "Califato/Emirato" global. Este, aparte de ser un tipo de organización política que en el imaginario occidental pertenece al pasado, se basaría en la sharia, la ley islámica que determina y gobierna tanto las esferas públicas —detalla, por ejemplo, el sistema de justicia civil o criminal, como las privadas- como los modos de culto, las reglas morales $y$ define el Bien y el Mal.

Por lo tanto, en este modelo de organización política no sólo las esferas volverían a ser unificadas eliminando la distinción de lo público y lo privado/religioso, sino que las leyes que gobernarían la parte política tendrían un origen religioso y no viceversa. En este sentido, se instauraría un modelo de organización social teocrático, basado en una forma de gubernamentalidad basada en principios religiosos que proporcionan unas leyes que engloban por entero lo público y lo privado y que se justifica y legitima a través de la presencia de un ser superior que, por lo tanto, no se puede cuestionar.

Y es aquí que encontramos, entonces, los elementos de dos proyectos políticos que son tan diferentes que llegan a ser incompatibles, sin quitarle a ninguno de los dos su legitimidad y que, por lo tanto, llegan a dar lugar a un enfrentamiento violento no sólo físico, sino que también ideológico, a lo que hemos llamado choque civilizatorio.

\section{Violencia mítica, violencia divina, violencia terrorista y estado teocrático como modernidad} Walter Benjamin, en Por una crítica de la violencia, distingue entre violencia divina y violencia mítica: "De la misma forma en Dios y mito se enfrentan en todos los ámbitos, se opone también la violencia divina a la mítica; son siempre contrarias" ". La justicia es el principio de toda fundación divina de fines y poder es el principio de toda fundación mítica del derecho ${ }^{98: " s i ~ l a ~ p r i m e r a ~(e n ~ e s t e ~}$ caso la violencia mítica) establece fronteras, la segunda arrasa con ellas; la mítica culpabilizadora y expiatoria, la divina es redentora; cuando aquella amenaza (violencia mítica), ésta golpea, si aquella es sangrienta ésta otra es letal, aunque incruenta (como veremos más abajo, incruenta a

\footnotetext{
97 BENJAMIN, Walter, Por una crítica..., op. cit., p. 4 I

98 Ibídem, p. 4 I
} 
su manera". La violencia mítica es fundadora de derecho, la violencia divina - aquella que tiene a "la justicia como principio de toda fundación divina de fines"

Si nos detenemos en la violencia que Benjamin denomina mítica, podemos ver que es mítica en un doble aspecto. Es mítica en el mito fundador del estado, de la comunidad y es mítica en la forma en que se gestiona el conflicto en las visiones contractualistas del estado, de la vida política. En primer lugar, el relato oficial del origen de la comunidad y del estado, su régimen de verdad, se construye por la superposición en el tiempo de mentiras que acaban creando un saber verdadero ${ }^{101}$. Cualquier historiador puede seguir el hilo continuo de la construcción de un estado - violencia al fin y al cabo, pues siempre se produce con una determinada correlación de fuerzas - y el discontinuo de los estallidos de violencia más abiertos y transparentes como las guerras $^{102}$

En segundo lugar, mítico, pues, como hemos visto, el contrato que fundamenta el estado, que se dice, representa a la comunidad es un contrato que se realiza en un ágora ${ }^{103}$ prístina, limpia y donde los iguales en ciudanía se dotan de una carta magna. Se obvia, pues sino no puede relatarse el cuento, que en algún momento se decidió por la violencia quiénes eran esos ciudadanos y quiénes no; que no hubo discusión pública elegante sino vencedores y vencidos, que en los pactos siempre se puede leer la correlación de fuerzas (violentas). Que las instituciones heredadas son violencia reglamentada y que las nuevas reflejan esa correlación de fuerzas entre vencedores y vencidos. Que como diría Hedley Bull ${ }^{104}$ sobre el sistema internacional, los acuerdos, aunque sean fruto de la derrota militar, tienen validez ${ }^{105}$.

La violencia divina, para Benjamin, no sólo se manifiesta en las revelaciones religiosas, sino mucho más en las expresiones sacralizadas de la vida cotidiana. Ésta se justifica como exterminadora, aunque lo sea de forma relativa, es decir, dirigida a bienes, derecho, vida y lo que se asocia con ellos:"jamás absoluta respecto al alma de los seres vivientes y por más sagrado que sea el ser humano, sus condiciones o su vida corporal que sus semejantes convierten precaria no lo son"106.

\footnotetext{
99 Ibíd., pp. 40 y 4 I

100 Ibíd.

${ }^{101}$ FOUCAULT, Michel, Nietzsche, op. cit

${ }^{102}$ En el caso español todo empezó con un pastor lusitano llamadoViriato que resistió y combatió la invasión de Roma,y podríamos eternizarnos en los ejemplos.

${ }^{103}$ Permítasenos una inconveniencia.Aristóteles era un tramposo: funda toda su filosofía política en la polis, cunado ésta ya no existía, había sido conquistada por un imperio. Es más fuera el preceptor del hijo,Alejandro, de aquel que acabó con ella, Filipo de Macedonia. En su bellas y nostálgicas primeras páginas de Tras la virtud, Alasdair Maclntyre nos habla de que, en la modernidad, sólo encontramos ruinas, fragmentos, vestigios de un pasado. MACINTYRE,Alasdair, Tras la virtud, Crítica, Barcelona, 1997.

A la manera del arqueólogo británico Arthur Evans que reconstruyó el palacio de Cnosos, supuesto centro de la cultura minoica (2.800. a. c. - I 200 a.c.) a principios del siglo XX (1923-1939) del que se dice que colocó ventanas balcón en el palacio por inspiración de las ventanas venecianas.

${ }^{104}$ BULL, Hedley, The Anarchical Society. A Study of Order in World Politics, Palgrave, Nueva York, 2002 [1977]

${ }^{105}$ En el caso de la historia reciente del Estado español, la jefatura del estado era una herencia de un régimen fascista nacional católico, por más que se le inventara un pasado limpiamente democrático; que la redacción de la construcción se realizó $a$ pachas entre representantes del antiguo régimen y de los emergentes; y que todo esto se produjo a apenas $17 \mathrm{kms}$. de una división acorazada comandaba por franquistas confesos y con los motores en marcha. Este régimen del 78 es el marco-poder-violencia, que proporciona el vocabulario de la doxa, que establece el régimen de verdad en el que se desarrolla ahora la política en esa inventad España.

${ }^{106}$ BENJAMIN, Walter, Por una crítica..., op. cit., pp. 42 y 43.
} 
Slavoj Žižek retoma el concepto benjaminiano de violencia divina interpretándola como una violencia, un medio, pero sin fines ${ }^{107}$. Sin embargo, el mismo Benjamin argumentaba que "la ira, por ejemplo, conduce a irrupciones más evidentes de violencia sin por ello ser medio para fin alguno" ${ }^{108}$. Sostiene Žižek que la diferencia entre Schmitt y Benjamin se encuentra en la consideración de este tipo de violencia: para Schmitt la violencia sólo es un medio para alcanzar una fin y por eso la violencia más radical que puede concebir es sólo la violencia mítica, violencia que sirve de fundamento al nuevo derecho; la violencia divina de Benjamin "es tal como dijo, una caso de medios sin fin [...] no es aquí medio sino manifestación"| ${ }^{09}$. En este sentido, los estallidos sociales que se dan, por ejemplo en EE.UU. cuyo ejemplo paradigmático serían los sucesivas revueltas del gueto de Watts en Los Ángeles, en 1965, 1997, o 2014, donde el estallido violento cuya chispa es, casi siempre, la actuación policial en el gueto, destruyo, saqueó (los comercios locales propiedad en su mayoría de coreanos), ataco a la policía y a la Guardia Nacional (cuerpo militar) que fue convocada por el gobernador del estado ante el desborde de las fuerzas policiales. Estas revueltas nos remiten a violencias estructurales, marginación, pobreza, paro, segregación y/o actuación policial; pero no fundan derecho, ni siquiera responden a una organización u organizaciones, ni a un programa o programas de transformaciones. Son medios sin fin. Ejemplos para Žižek de la idea de violencia divina de Benjamin ${ }^{110}$.

Otro autor que cabe mencionar es Eduardo Grüner, quien escribe en paralelo a Žižek. Para él el "fundamentalismo es violencia fundadora que no encuentra nada que fundar" "II. El autor argumenta que "de ahí su recurso extremo a una aparente irracionalidad"|'2. Merece tener en cuenta estas opiniones, reforzadas, como veremos más abajo, por las posiciones de Alain Badiou'113. Aunque resulte chocante que se diga de Daesh/lsis que no tiene nada que fundar ni fundamento. Merece la pena recogerlas y pensarlas con calma y tiempo.

La violencia ejercida por el Daesh o por al-Qaeda, el germen de estado teocrático establecido por el primero en las zonas bajo su control, sus agravios, reivindicaciones, odios y objetivos no son algo que podamos analizar con el tradicional binomio moderno/tradicional. Estos fenómenos son modernos, en primer lugar, porque se están produciendo en el siglo XXI, en segundo, porque, aunque combata la modernidad occidental, no son vestigios de formas tradicionales medievales (sin contar que por "tradicionales" se designa a aquellos que no aceptan la modernidad europea). Son una respuesta a fenómenos modernos, desde la mundialización del capital, la correlación de fuerzas político-militar, la riqueza esquilmada del territorio etc. ${ }^{114}$. Y son tan modernos como los tiempos de los que son fruto, sólo hace falta pensar en el uso de los medios sociales o de las nuevas tecnologías que éstos hacen. Éstos representan otra vía de supervivencia en este mundo moderno, una vez fracasada la vía nasserista del nacionalismo árabe.

\footnotetext{
107 ŽlŽEK, Slavoj, La nueva lucha de clase..., op. cit.

${ }^{108}$ Ibídem, p. 46. Citando a BENJAMIN, Walter, Por una critica..., op. cit.

109 ŽlŽEK, Slavoj, La nueva lucha de..., pp. 44 y 45, citando a Benjamin Por una crítica....

110 Ibídem, p. 44 y ss.

I"' GRÜNER, Eduardo, Las formas de ..., op. cit., p. 8 I.

112 Ibídem, p. 128.

${ }^{113}$ BADIOU,Alain, Nuestro mal..., op. cit.

114 GRAY, John, Al Qaeda y lo que significa ser moderno. Paidós, Barcelona, 2004. BEHNKE, Andreas, "El Terror y lo Político: el II-S en el Contexto de la Globalización de la Violencia", Relaciones Internacionales, 20I3, vol. 23, pp. II7-I 46.
} 
Por su parte, "el estado llamado teocrático (que interioriza y sustenta valores estales y, por lo tanto, modernos), en la medida en que el orden mundialmente dominante le impone articular su fundamentalismo con la racionalidad de la división internacional del trabajo" 115 y que siguiendo a Kenneth Waltz, los estados se ven en la necesidad de "copiar las prácticas de mayor éxito (más eficaces)" ${ }^{\prime \prime}$ en el sistema internacional.

Ni importa que se remitan a libro escrito en el siglo XVI, no importa que se remitan a situaciones pasadas y mitificadas como el Califato ${ }^{17}$. Los fundamentalistas cristianos se remiten a la Biblia, los judíos al Talmud, etc. Esto es algo que todas las culturas modernas tienen en común. La línea divisoria, la línea de enfrentamiento se encuentra en lo que distingue la modernidad occidental de esta otra modernidad (que probablemente niega esta condición) es el proceso, movimiento, pensamiento, imaginario social de secularización. Las sociedades occidentales se ven a sí mismas como seculares, y no nos importa aquí que sea sólo una ficción operativa, ni que existan manifestaciones religiosas más o menos asumidas por el estado. La secularización, división de la vida social en esferas distintas, tal como la hemos definido y descrito más arriba, forma parte del imaginario social occidental y de su doxa.

La violencia divina (búsqueda de la justicia o simplemente expresión de rabia) puede convertirse, en condiciones sociales y políticas de crisis y si existe una organización capaz de dotar al significante vacío de contenido, en violencia mítica, fundadora de un derecho nuevo fruto de la decisión de la organización de la revuelta/revolución. Esta violencia terrorista, es, desde luego, en términos benjaminianos, violencia divina, no realizada en el sentido que no ha creado derecho - salvo en el territorio dominado por el Daesh- pero lucha por crearlo. Es, en cualquier caso, violencia política, violencia con objetivos políticos. Si es o no solamente violencia divina y en qué sentido, lo examinaremos más adelante.

La difusión del mensaje a través de redes no formalmente organizadas y la capacidad de cualquier sujeto o colectivos de sujetos de situarse bajo el discurso de al-Queda o del ISIS sin que necesariamente haya vínculos formales — poder extensivo, en términos de Mann ${ }^{118}$ _, permite que esa violencia mítica sirva de paraguas donde se inscribe lo que Benjamin y, sobre todo, la lectura de Žižek de los conceptos benjaminiano, denominan violencia divina ${ }^{119}$, o lo que Grüner llama fundamentalismo que no encuentra fundamento.

Etienne Balibar ${ }^{120}$ discute en el contexto del fin de la Guerra Fría, el II-S y las nuevas guerras - The War on Terror de Bush-y en el contexto de los análisis de Mary Kaldor ${ }^{121}$ y Van Creveld ${ }^{122}$, si la palabra guerra es adecuada y si la obra de Clausewitz sigue estando vigente para el conflicto en Oriente Medio y Afganistán y sus repercusiones (atentados) internacionales. Para

\footnotetext{
${ }^{115}$ GRÜNER, Eduardo, Las formas de..., op. cit., 91.

${ }^{116}$ WALTZ, Kenneth, Teoría de la política internacional, GEL, Buenos Aires, I988, p. 20.

117 GREY, John, Al Qaeda..., op. cit.

118 MANN, Michael, The Sources of Social Power.The Rise of Classes and Nation-States, I 760-19/4, Cambridge University Press, Cambridge, I993, p. 7.

119 ŽIŽEK, Slavoj, La nueva lucha de clase..., op. cit.; BENJAMIN, Walter, Por una crítica..., op. cit.

${ }^{120}$ BALIBAR, Etienne, “What's in a War? (Politics as War, War as Politics)”, Ratio Juris, Vol. 21 , n 3, 2008, pp. $365-386$.

${ }^{121}$ KALDOR, Mary, New and Old Wars. Organized Violence in a Global Era, Stanford Universty Press, Stanford C.A., I999.

${ }^{122}$ Van CREVELD, Martin, The transformation of War, Free Press, Nueva York, I99।.
} 
empezar Balibar reflexiona si lo que nos traemos entre manos es una guerra. Las denominaciones (naming the event) y etiquetas - como guerra - tienen su importancia: "sabemos que nombrar/ denominar un evento es, al mismo tiempo, decir que hay un evento (y) una operación, en la que los sujetos son ellos mismos parte del objeto que están considerando"|23. Cuando la Administración Bush habló de War on Terror estaba, según el autor, sugiriendo que las concepciones clásicas de la guerra ya no eran ni válidas ni útiles ${ }^{124}$. De hecho, en la expresión se juntas dos términos que deberían ser binarios: la guerra -actividad de ejércitos que pertenecen a un Estado y que está regulada por el derecho internacional y humanitario - y el terror- actividad llevada a cabo por combatientes ilegales fuera del marco de lo legal-. En esta expresión War on Terror, o, por ejemplo, en la solemne declaración del presidente francés Hollande de declarar guerra al ISIS se ponen así entre paréntesis todas las convenciones que hasta entonces habían intentado humanizar la guerra. Pues, como mencionado antes, contra el partisano se lucha de forma partisana ${ }^{125}$.

Balibar sostiene que hay tres aspectos en los que la guerra que libra EE.UU. en Oriente Medio, y que engloba muchas otras "guerras". Ésta es, en aspectos muy importantes, una guerra según los cánones de Clausewitz:"es una guerra larga, cuyo fin no puede vislumbrarse y en la que las tensiones entre los objetivos militares y los políticos de forma creciente producen efectos de fricción ${ }^{126}$. Además de los discursos políticos que la describen así, como mencionado antes, si luchamos en contra del MAL nuestra guerra será eterna puesto que es imposible erradicar enteramente al EVIL del mundo.

Podemos encontrar estos aspectos clausewitzianos en el War on Terror y el terrorismo. En primer lugar, desde que la Revolución Francesa con su leveé en masse, introdujo la conscripción en todos los ejércitos europeos; y desde que la guerra se industrializó en la Primera Guerra Mundial, el concepto de guerra total es el que mejor se ajusta a las guerras contemporáneas. Al poner toda la economía de la nación, toda su industria, y toda su población al servicio de los objetivos militares, la clásica distinción entre militares y civiles (personas y/o objetivos) se difumina. Puede ser más importante destruir una ciudad que ganar en una batalla de carros blindados.

En segundo lugar, las guerras se ganan en "casa del enemigo": Alemania no capituló en 1918 porque la Entente hubiera roto el frente — por una derrota militar - sino por agotamiento económico y crisis político-social, que más tarde dio origen a la República de Weimar.Vietnam es otro ejemplo alejado de las guerras europeas de grandes ejércitos en posiciones o en movimiento), las fuerzas norteamericanas se retiraron de Vietnam, no por haber sufrido una aniquilación o un Bien Dien Bien Fu, como los franceses, sino porque la opinión pública de EE.UU. no quería más guerra que no entendía; las universidades y los guetos estaban en pie de guerra, el ejército estadounidense tenía claros síntomas de descomposición, etc.

En tercer lugar, las bombas, los atentados han sido de siempre armas de los movimientos de

\footnotetext{
${ }^{123}$ BALIBAR, Etienne, “What's in a War?...”, op. cit., p. 368.

${ }^{124}$ Ibídem, p. 368.

${ }^{125}$ SCHMITT, Carl, The Theory of..., op. cit.

${ }^{126}$ Balibar sostiene que el concepto de fricción es central en el pensamiento de Clausewitz. Tiene que ver con la duración, lo imprevisible de su desarrollo, etc. Argumenta el autor que "La noción clausewitzianos de la relación entre política y guerra implica la posibilidad de que los factores políticos transformen las condiciones del enfrentamiento militar, $y$ a su vez, que la <fricción> de la guerra influencie sus caracteres y condiciones políticas”. En BALIBAR, Etienne, “What's in a war?...”, op. cit., p. 376.
} 
liberación nacional. Isaac Rabin, primer ministro del Estado de Israel (1974-77), recibió el Premio Nobel de la Paz en 1994 por las conversaciones de Paz de Oslo. Desde 1941 miembro destacado de los grupos de élite de la Haganá; Menajen Begin, otro primer ministro de Israel, Premio Nobel de la Paz en 1978, fue líder máximo del Irgún y responsable de la voladura del Hotel Rey David el 22 de julio de 1946, donde se asentaba el Estado Mayor y la Administración Civil británica; en 1948 estas organizaciones asesinaron a tiros a Folke Bernadotte, Conde de Wisburg, jefe de la misión mediadora de Naciones Unidas en la guerra de 1948. El Frente de Liberación Argelino en su lucha por la independencia de Argelia (1954-1962) realizo una campaña de atentados en la metrópoli; el Irish Republican Army, cuyo brazo político, el Sinn Féin hoy está en el gobierno de Irlanda del Norte y es el tercer partido en el parlamento de la República de Irlanda, realizó innumerables atentados en Inglaterra. Pero bombas utilizadas masivamente, fueron las que lanzaron las oleadas de bombarderos norte americanos sobre Vietnam del Norte, sin búsqueda alguna de objetivos militares, incluso cunado Kissinger consideraba que la tozudez de los negociadores vietnamitas podía ablandarse con otro bombardeo masivo más.

En cuarto y último lugar, el terror forma parte de las estrategias militares desde el siglo pasado. El intensivo bombardeo de Londres por parte alemana, sobre todo entre julio y octubre de 1940, tenía como objetivo "minar la moral de la población”, que no era otro el propósito del carpet-bombing (all around the clock) angloamericano sobre Alemania, como la destrucción total de la ciudad de Dresde. Debilitar la moral de la población es el eufemismo militar de crear y expandir el Terror. Desde luego que éste es una arma político-militar utilizada por respetables y respetados gobiernos o futuros gobiernos. En un mundo de drones, el tiempo y el espacio se achican, las imágenes destinadas a crear el terror — degüellos filmados, por ejemplo— son para los más débiles militarmente, lo que los B-52s, también filmados y retrasmitidos en acción por TV, para Kissinger.

La violencia directa - “la vieja potencia de la muerte en la cual se simboliza el poder soberano" 127 _ opera como signo del poder.Argumenta Byung-Chul Han que "en el teatro de la crueldad se representa el poder del soberano como el poder de la espada [...] La pomposidad de la puesta en escena de la pena de muerte manifiesta el poder y la magnificencia del señor" ${ }^{28}$. En este teatro donde todo se filma y se cuelga en la red, la crueldad —el degüello televisado- debe presentarse ante el público para ser efectivo como arma de guerra, como terror. Los drones o los asesinatos selectivos de las fuerzas occidentales no necesitan tanto ese espectáculo ${ }^{129}$. Son las muertes y los degüellos televisados un ritual, un teatro donde se está diciendo “¡lo veis puedo hacerlo! ¡tengo el poder de hacerlo!’. Pero el poder que tiene que explicitarse, que salir a escena y ser visto es el poder débil. El poder fuerte no necesita de reconocimiento - de hecho, menos se sabe de sus acciones, mejor, para poder mantener una cierta legitimidad (y credibilidad). Sucede igual que con los nacionalismos: el satisfecho se disfraza de cosmopolitismo racional, ecuánime y templado y se escandaliza de la escandalera de otros; el nacionalismo insatisfecho grita, patalea y se revindica constante y poco discretamente. Los drones ( 10 bajas por la muerte de un objetivo ${ }^{130}$ )

\footnotetext{
${ }^{127}$ FOUCAULT, Michel, Historia de la sexualidad I. La voluntad de poder, Siglo XXI, Madrid, 2005, p. 169.

${ }^{128}$ HAN, Byung-Chul, Topología de ..., op. cit., p. 17

${ }^{129}$ Y, de hecho, en la mayoría de las veces, se prefiere rehuir el espectáculo puesto que estos bombardeos están al límite de la legalidad proporcionada solo por lo que se define "collateral damage"- $y$, sin embargo, fuera del respeto de los derechos humanos

${ }^{130}$ BADIOU, Alain, Nuestro mal..., op. cit., pp. 76 y ss.
} 
de unos son los atentados de los otros.

Es lo que Zolo califica de ceremonias letales que juegan una función particular en las estructuras y prácticas del poder político ${ }^{131}$. Pero el uso del terror como arma política no es sólo cosa de aquellos que usan la violencia para establecer un nuevo derecho mítico. Es una de las prerrogativas del estado: tomar la decisión de declarar — de facto o de jure- el estado de excepción. Así lo hicieron los militares latinoamericanos con la Operación Cóndor, "un sistema transnacional de desaparición de personas" ${ }^{32}$ en la que todo el mundo se sentía una víctima en potencia $^{133}$.

Un rasgo, tampoco muy original, de esta violencia es que se dirige muy a menudo a aquellos de entre los suyos o cercanos que no comulgan con sus ideas o que se oponen a ellas. Es lo que se narra en el film La Batalla de Argel ${ }^{134}$ : antes que nada, para lograr hacer de la casbah de Argel un bastión de la insurgencia del FLN hay que limpiarla, en términos militares clausewitzianos se podría hablar de asegurar la retaguardia. Pero, de hecho, la guerra en la que se sustenta el ISIS tiene tal cantidad actores, anuda tantas brechas distintas y tantos conflictos que se podría decir que, en Siria, Irak, etc. la actuación terrorista ${ }^{135}$ de ISIS/Daesh o de la rama local del al-Qaeda -coches bomba o explosiones suicidas en Damasco o Bagdad - pretende sembrar el terror de forma más convencional que en los caos de París, Bruselas, Alemania, etc. En el primer caso los atentados son similares al carpet bombing aliado en la IIGM y el segundo más parecido a la actuación del FLN en Francia o el IRA en Inglaterra.

Finalmente, si como sostiene Williams la modernidad está marcada por una específica búsqueda de la seguridad ${ }^{136}$, esta búsqueda es incesante y adquiere rasgos propios en las diferentes coyunturas históricas. Después de dos guerras mundiales y 45 años de una guerra fría que mantenía al mundo al borde de la aniquilación nuclear, desde hace años e intensificándose, Occidente se siente amenazado por el fenómeno terrorista. Es en este contexto que se produce la lógica de seguridad - supervivencia - que da lugar a la securitización, es decir, a la implementación de medidas extraordinarias para evitar o resguardarse de ese riesgo: "un movimiento que lleva la política más allá de las reglas de juego establecidas y enmarca el problema una especie de política por encima de la política (politics above politics)"'137.

\footnotetext{
${ }^{131}$ Danilo Zolo citado en JACKSON, Richard y DEXTER, Hellen, "The Social Construction of Organized Political Violence: An Analytical Framework", Civil Wars, vol. 16, n'. I, 20I4, p. 3

${ }_{132}$ LOBO, Ramón, “El mejor amigo del ISIS, nuestra estupidez, Infolibre, 22 de julio de 2016, http://www.infolibre.es/noticias/opinion/2016/07/20/ el_mejor_amigo_del_isis_nuestra_estupidez_52705_1023.html

${ }^{133}$ La operación Cóndor como terrorismo de estado está bien explicada en CAÑON, Lisandro, "Terrorismo de estado. El sur del continente americano durante la década de 1970. Un caso de transnacionalización del terrorismo estatal", Revista de Relaciones Internacionales, núm. 32, 2016.

134 1965, dirección de Gillo Pontecorvo.

${ }^{135}$ Aquí el término "terrorismo" es aún más arbitrario. En Siria e Irak el combate es convencional, de movimientos y cercos, etc. Aunque hay coches bomba en Damasco y en Bagdad

${ }^{136}$ WILLIAMS, Michael C., "Identity and the politics of security", European Journal of International Relations, vol. 4, n⿳ 2, 1998, pp. 204-225. Ver también, VERDES-MONTENEGRO ESCÁNEZ, Francisco Javier, "Securitización: agendas de investigación abiertas para el estudio de la seguridad", Relaciones Internacionales, vol. 29, 20I5, pp. III-I3I. BUZAN, Barry, WÆEVR, Ole, de WILDE, Jaap, Security: A New Framework for Analysis, Lynne Rienner Publishers, Londres, 1998.

${ }_{137}$ Ibídem. p. 164.Y en p. 166. Por ejemplo, Tony Blair, horas después del atentado del metro en Londres, 7 de julio de 2005, afirmo "las reglas de juego están cambiando (the rules of the game are changing)".
} 
Es lo que, para Schmitt, sería la (estado de) excepción al margen de ley y decretada por decisión del soberano ${ }^{138}$. Efectivamente, "soberano es quién decide sobre el estado de excepción" que, como remarca Alain de Benoist, significa tanto que "él quién decide en una situación excepcional es soberano, pero también quién decide sobre la excepción misma es soberano, o sea, él que decide que la situación ya no es normal y que las reglas ordinarias ya no se aplican" 139 . Pero detrás de esta despolitización de la seguridad, no sólo se encuentra el peligro y el terror como sucedía con el FLN argelino o el Ira irlandés- sino también las diferencias de concepción del mundo, de la vida social y de vocabulario.

Es lo que, para Schmitt, sería la (estado de) excepción al margen de ley y decretada por decisión del soberano ${ }^{140}$. Efectivamente,"soberano es quién decide sobre el estado de excepción"|41 que, como remarca Alain de Benoist, significa tanto que "es él quién decide en una situación excepcional es soberano, pero también quién decide sobre la excepción misma es soberano, o sea, él que decide que la situación ya no es normal y que las reglas ordinarias ya no se aplican"|42. Pero detrás de esta despolitización de la seguridad, no solo se encuentra el peligro y el terror - como sucedía con el FLN argelino o el Ira irlandés- sino también las diferencias de concepción del mundo, de la vida social y de vocabulario.

\section{Nuestras enmiendas. La mundanización de la acción humana y de su tiempo histórico ${ }^{143}$ según Nietzsche,Weber, Schmitt, Morgenthau}

Esta concepción del ámbito propio de lo político tiene su base material e ideacional no sólo en la experiencia europea del siglo XVII, sino en la "fragmentación de los fenómenos y las experiencias de lo social, indicada en la teoría de Max Weber acerca de la 'autonomización' de las esferas"|44 (económica, política, cultural, religiosa, etc.) bajo el imperio de la racionalización burocrática mundial, característica de la modernidad. Este efecto de la modernidad impuesto por la expansión imperialista europea sobre los otros es, quizás, uno de sus más grandes agravios.

Los conceptos de lo político que manejamos —un eco de Nietzsche ${ }^{145}$, Weber $^{146}$, Schmitt ${ }^{147}$, Benjamin $^{148}$, Morgenthau ${ }^{149}$, Carr $^{150}, y$, hoy en día, Mouffe ${ }^{\mid 51}$ - tienen en común varios rasgos y

\footnotetext{
${ }^{138}$ MAVELLI, Luca, "Between Normalisation and Exception:The Securitisation of Islam and the Construction of the Secular Subject",Millennium: Journal of International Studies, vol. 4I, $\mathrm{n}^{\circ}$ 2, 20I3, pp. I59-18I.

${ }^{139}$ DE BENOIST,Alain, Carl Schmitt Today.Terrorism, “Just”War, and the State of Emergency, Arktos Media, Londres, 2013 , p. 76.

140 MAVELLI, Luca, “Between normalization...”, op. cit., p. 4I.

${ }^{141}$ SCHMITT, Carl, “The Concept of the...”, op. cit, p. 34.

142 DE BENOIST, Alain, Carl Schmitt today..., op. cit., p. 89.

${ }^{143}$ Este epígrafe se inspira en la brillante tesis doctoral de Ángela Iranzo, Continuidades del factor religioso, op. cit.

${ }^{144}$ Citado por GRÜNER, Eduardo, Las formas de..., op. cit., p. II4

145 Por ejemplo, NIETZSCHE, Friedrich, Genealogía de la moral, Alianza Editorial, Madrid, 1972; aunque proliferan las ediciones.

${ }^{146}$ Hay innumerables ediciones. La que hemos tenido a mano es, WEBER, Max, La ciencia como profesión. La política como profesión, Austral, Madrid, 1992 editado y traducido por Joaquín Abellán

${ }^{147}$ SCHMITT, Carl, El concepto y de lo político..., op. cit. SCHMITT, Carl, Teoría del partisano..., op. cit.

${ }^{148}$ BENJAMIN, Walter, Para una crítica de..., op. cit.

149 MORGENTHAU, Hans, The Concept of the Political, Palgrave Macmillan, Nueva York, 20I2, traducción del original en francés publicado en 1932 en Francia.

${ }^{150}$ CARR, E. H., The Twenty Years', op. cit.

${ }^{151}$ MOUFFE, Chantal, Agonistics..., op. cit..
} 
también se podría decir los mismo - seculares, separadores y occidentales - del aristotelismo de Arendt o del kantianismo o neokantianismo de Habermas. Por ejemplo, y que no compartimos: son modernos, seculares y de matriz occidental e incluso, salvo Nietzsche, Weber y Carr, forjados en la República de Weimar. En ese sentido delimitan un ámbito de lo político propio, Morgenthau insiste mucho en ello, que supone una separación y una concepción particular —-por ejemplo, no kantiana - de esferas o ámbitos de la vida social y del tiempo histórico.

El ámbito de lo político — contra Arendt y contra Kant- para estos autores y para nosotros, que compartimos sus posiciones, concibe la política como conflicto sobre las visiones del mundo, prebendas y agravios, formas de vida, relatos sobre la(s) historia (historias), contenido que se les da a los significantes vacíos de la modernidad como libertad, justicia, etc. La historia es, parafraseando Nietzsche, el eterno comienzo, en el que da las soluciones a los conflictos son las semillas de las futuras contradicciones y luchas.

El ámbito de lo político para nuestros autores no es una discusión igualitaria y sin violencia (ni estructural ${ }^{152}$ ni directa) o una correlación de fuerzas, sobre la vida y las miserias (y expectativas) de la polis ${ }^{153}$, a lo Arendt, sino el ámbito del poder, entendido, desde luego no en el sentido materialista mecanicista de la ciencia política de matriz estadunidense. El concepto de poder varía ligeramente entre estos autores, pero esencialmente es el mismo.

En nuestros días esta herencia es recogida por Chantal Mouffe en su concepción agonística de lo político que sostiene el abandono de cualquier sueño de la idea de armonía social y sostiene “(cuando hablo de) 'lo político' me refiero a la dimensión ontológica del antagonismo y por 'política' (politics) el encaje de prácticas e instituciones cuyo fin es organizar la existencia humana" ${ }^{54}$.Y más, la posibilidad siempre presente del antagonismo porque no puede concebirse una sociedad sin división y poder ${ }^{155}$.

El concepto moderno de lo político a lo Schmitt, Morgenthau ${ }^{156}$, etc., religioso en origen — "todos los conceptos políticos modernos son conceptos teológicos secularizados" 157 , como sostiene Schmitt en su Teología política- pero secularizados, "mudanizados" inmanentes a lo humano y no transcendentes y por tanto con una gramática y vocabulario moderno, sólo se da dentro de una constelación civilizatoria. Es como funcionó, de hecho, está en su origen, el equilibrio en el sistema europeo de estados desde Westfalia —más o menos. Es también lo que Grüner llama una ficción operativa ${ }^{158}$.

El concepto de lo político moderno se plasma también en otra corriente: aquella que defiende la idea de progreso en términos teleológicos, es decir, las férreas líneas de la Historia -

\footnotetext{
${ }^{152}$ GALTUNG, Johan, “Violence, Peace and Peace Research”, en Journal of Peace Research, vol. 6, n 3, 1969, pp. 167-191.

${ }^{153}$ Aristóteles habla de la polis en un espléndido aislamiento. Pero la polis, como toda comunidad política, se constituye a partir de la distinción entre nosotros y los otros. Es decir, a lo Schmitt, la polis sólo adquiere identidad y unidad frente a sus enemigos.

${ }^{154}$ MOUFFE, Chantal, Agonism..., op. cit., p. XI.

${ }^{155}$ Ibidem, Pp. XI-XV y I.

${ }^{156}$ MORGENTHAU, Hans, The concept of the political..., op. cit.

${ }^{157}$ SCHMITT, Carl, Teología..., op. cit., p. 20.

${ }^{158}$ GRÜNER, Eduardo, Las formas de..., op. cit..
} 
las relaciones de producción en contradicción con las fuerzas productivas pujantes y se abre una época de revolución social como sostiene Marx (en su versión más cientifista y mecanicista) ${ }^{159}$. No es el caso de los autores que nos inspiran - Nietzsche Weber, Schmitt, Morgenthau, etc. — pero sí el de los planteamientos kantianos y neokantianos y el de los marxistas más clásicos. La idea de progreso inevitable sigue viva - por ejemplo, la habitual categorización de países desarrollados o subdesarrollados o el eufemismo en vía de "desarrollo"- pero tanto la idea del inevitable progreso como la de una intrínseca, todavía no manifiesta armonía de intereses, se tambalean y debilitan, en los discursos occidentales, por la lectura del trágico y breve ${ }^{160}$ siglo $\mathrm{XX}$.

Tal concepto de lo político no existe en el "terrorismo islámico”. Es más, éste es tan fruto de la modernidad como el concepto occidental ${ }^{161}$, pero a la vez se basa en su rechazo de esa modernidad impuesta por el colonialismo y que ha fracasado en los proyectos modernizadores a lo Nasser, Baath, en el llamado nacionalismo árabe de los 50 y 60 del siglo XX. Está corriente, llamada "yihadista" o "islamismo radical" — podríamos hablar de la filosofía política del "terrorismo"niega la separación de la vida social en esas esferas mencionados: lo político -el poder-, la autoridad, la religión, la organización social, etc. no pueden y no deben separarse y distinguirse nítidamente. En realidad, es un fenómeno moderno de rechazo a determinada modernidad, de defensa de la desestructuración arrasadora del capitalismo global y de la modernidad occidental y la restauración de una concepción histórica, no parcelada y con fuertes fundamentos trascendentes de la vida social.

En resumen, y desde el punto de vista de los no expertos en el tema, las condiciones materiales e ideacionales del discurso, la práctica y la organización del "terrorismo islámico" podrían enumerarse en: los agravios materiales e ideacionales de carácter histórico (no es casualidad que designen a los occidentales como cruzados y/o francos); una situación económica que combina la inmensa riqueza de determinadas élites - los príncipes saudíes y de los emiratos del Golfo- y la pobreza de la mayoría de la masas árabes e islámicas acentuada en el caso de Irak por la invasión estadounidense del 2003 y su política de reconstrucción; la interminable guerra de Afganistán fruto de la invasión de la OTAN y cuyo fin no aparece, ni aparecerá, en el horizonte; la imposición exterior y local de determinados parámetros y formas de pensar y de gestionar la producción y distribución de la riqueza en temas que van desde la fronteras coloniales, los intentos occidentalizado res del llamado "nacionalismo árabe" que sucumbió en las derrotas militares frente a Israel; ideacionales y civilizatorios: la versión del Islam saudita wahabita y de los Hermanos Musulmanes ha resistido - estrictamente resistir sólo es aplicable a los Hermanos Musulmanes que fueron perseguidos por Nasser, etc.: los agravios frente a los intentos de secularización de Occidente y locales y la sensación que estos producen de "quitar el suelo bajo los pies" de la gente; la brecha real en lo religioso, en lo social, $y$ en la detentación del poder político entre suníes y chiitas, acentuada por la peculiar guerra fría entre Irán e Arabia Saudita en la zona.

\section{La conclusión práctica}

La conclusión práctica provisional, no exhaustiva, escéptica y pesimista es que el conflicto no tiene solución. Y, es más, como la "solución" a un conflicto siembra las semillas de otro o de otros, la

\footnotetext{
${ }^{159}$ Prefacio al prólogo de MARX, Karl, Una contribución a la crítica de la economía política, Editorial Progreso, Ciudad de México, 1989.

${ }^{160}$ HOBSBAWM, Eric, Age of extremes. The short twentieth century, 19/4-199I. Abacus, Londres, 1994.

161 GREY, John, Al Qaeda..., op. cit.
} 
conflictividad internacional no desaparecerá. Pero esto último es filosofía de la historia. Volvamos al presente. Proponemos una conclusión escéptica por varias razones.

En primer lugar, el sistema internacional, en cualquiera de sus esferas, es profundamente injusto, jerárquico y conflictivo. Esta situación parece que no tiene visos de cambiar. Lo es desde hace siglos, y no se vislumbran fuerzas que creen un imaginario social diferente e incitante a la lucha por ese nuevo mundo imaginado. En palabras de Galtung ${ }^{162}$, se ejerce una continua y fuerte violencia estructural sobre los más pobres y no hay conflicto - que, por cierto, en este sentido, siempre será asimétrico- que pueda cambiar esto.

En segundo lugar, el caldo de cultivo, es decir, los agravios y el descrédito de los procesos de modernización (¿occidentalización? ${ }^{163}$ ) de los años 50 y 60 que murieron hace años, fracasando rotundamente y la invasión del capitalismo global. La (mal) llamada Primavera árabe fue liquidada por las propias élites de los países en los que se produjo, y si esa primavera hubiera supuesto una salida política las castas respectivas se encargaron de taponarla a través de represiones que fueron cuanto más violentas más exitosas, como en el caso de Egipto con la restauración de facto del régimen de Mubarak, o de Túnez, occidentalizado a la fuerza gracias a un contragolpe militar, o de Libia, destrozadas por luchas internas para sustituir a Gadaffi y por los efectos de la intervención occidental, Bahréin, donde las manifestaciones de la mayoría chiita fueron duramente reprimidas, o la intervención de Arabia Saudita en Yemen, etc. Los agravios son antiguos, de siglos, las fronteras son de origen colonial, la brecha entre ricos y pobres interna e internacionalmente se ensancha. Además, con la crisis, crece en los países occidentales la xenofobia y su consideración civilizatoria y/o teológica de las diferencias.

En tercer lugar, los contendientes cuya fuerza es manifiestamente desigual en términos económicos y sobre todo militares seguirán usando la fuerza. La de unos son los drones, la de otros son las bombas suicidas. Cualquier objeto puede causar daño, cualquier muerte es, en palabras de Schmitt, una manifestación de soberanía. Además, los contendientes, o todas las partes en conflicto ${ }^{164}-\mathrm{y}$ sobre todos sus patrocinadores - se han asentado cómodamente en ese desplazamiento de lo político a los teológico/civilizatorio, pues no sólo existe, como hemos visto, una razón/lógica/rationale de civilización, sino que el conflicto es utilizado por los estados o élites para tomar medidas internas que refuercen los dispositivos represivos. Esta retórica y discurso teologizado o civilizatorio, en cualquier caso, no es sólo retórica, que también, sino discurso creador de realidades.

La novedad de Daesh/lsis frente a otros grupos como al-Qaeda, es la posesión de territorio y su intención de instaurar en él un estado. Este grupo ha tenido un comportamiento diferente de los otros grupos "terroristas" internacionales - o, por lo menos, de los que más atención han recibido en Occidente ${ }^{165}$ _ En el junio de 2014, al Baghdadi se autoproclamó califa y la

\footnotetext{
162 GALTUNG, Johan, “Violence...," op. cit.

${ }^{163}$ PEÑAS ESTEBAN, Francisco Javier, Occidentalización, fin de la Guerra Fría y relaciones internacionales, Alianza Editorial, Madrid, I997.

${ }^{164}$ Quizás para el Gobierno sirio de Assad, para lo grupos rebeldes originales antes de la llegada de Isis y para el gobierno ruso el conflicto no sea teológico -aunque puedan utilizar ese discurso, sino civil y estratégico-.

${ }^{165}$ Hay que admitir que ISIS no fue el único grupo "terrorista” o "terrorista islámico" que consiguió controlar territorio. Por ejemplo, Boko Haram también, respondiendo a lógicas territoriales pero también socio-económicas.Ver RAINERI, Luca y MARTINI,Alice,“ISIS and AI-Qaeda as Strategies and Political Imaginaries in Africa:A Comparison between Boko Haram and Al-Qaeda in the Islamic Maghreb”, Civil Wars, vol. I 9,
} 
organización declaró su soberanía sobre los territorios de Siria e Iraq que había conquistado militarmente. En consecuencia, el grupo —que pasó a llamarse simplemente Estado Islámicohabía conseguido controlar militarmente territorios y montar unas fuerzas de lucha armada ${ }^{166}$. Sin embargo, encontramos la misma retórica en al-Qaeda e ISIS de lucha contra el MAL, de cruzados/ francos, etc.

\section{Algunos comentarios (teóricos) finales}

Alguien dijo que "la necesidad de la Razón no está inspirada por la búsqueda de la Verdad sino por la búsqueda del sentido"167 La afirmación es extremadamente sugerente, tanto más cuando la Verdad es algo que se nos escapa constantemente, tan a menudo, a pesar de nuestros duros esfuerzos, que nos lleva a sospechar que en realidad buscamos una quimera, un espejismo cultural que en realidad funciona, por lo menos desde la llustración del XVIII, como una forma de dar sentido al mundo. Nuestros discursos, nuestros relatos y nuestro leguaje que marca los límites de nuestro mundo no son ni serán nunca la Verdad sino nuestros mapas cognitivos y de sentido para manejarnos en la vida. Si dejamos a un lado a aquellos firmemente seguros de que la Verdad les pertenece y la dominan, con los que cualquier diálogo es imposible en última instancia, o el nihilismo y vitalismo absoluto del carpe diem — ni Verdad, ni sentido sino hay que aprovechar la vida- y aquellos que por miopía política social, o filosófica no ven más allá de lo que Weber denominó "razón instrumental", la búsqueda de sentido para sobrevivir o para morir y matar — puesto en la situación límite ("la excepción es más interesante que la regla”|68) que según los autores que más abajo glosaremos demuestra en su desnudez la esencia de lo político- tiñe las estructuras materiales y discursivas de injusticias y agravios, los esfuerzos de los agentes que promueven los discursos y narrativas que convierten el potencial social de violencia política en violencia actual y violencia como solución ${ }^{169}$. Esta violencia (política) es respondida militar y discursivamente desacreditada y maldita como un sinsentido, como una manifestación de salvajismo animal: puro deseo de sangre.Y, sin embargo, la propia muerte adquiere para los que deciden convertirse a sí mismos en armas letales da sentido a una existencia. Sentidos y sinsentidos antagónicos, pero letales para ambas partes. Difícil solución.

En este trabajo hemos querido llevar un poco más allá de nuestra inicial postura sobre la crítica al concepto de terrorismo, más especificadamente el "terrorismo" así llamado "islámico". $Y$ en el camino hemos aprendido algunas cosas:

\section{I. La reivindicación de un realismo político existencial.}

La rotunda crítica de Nietzsche al discurso de la modernidad ilustrada $-\mathrm{y}$ dejando de lado el tono grandilocuente, como corresponde a finales del siglo XIX, y wagneriano de algunos de sus textos $^{170}$ _ pone las bases para el despliegue de un hilo filosófico y de teoría social que lee el

\footnotetext{
$\mathrm{n}^{\circ} 4,2017$, pp. $425-447$.

166 MARTINI,Alice, “El terrorismo global como amenaza al orden internacional. El caso del Estado Islámico”. Relaciones Internacionales, 20I6, p. 85. Asimismo, hay que recordar, que a nivel político (y simbólico), el El ha proclamado el fin del tratado de Sykes-Picott, el acuerdo entre Francia y Reino Unido que repartió los territorios del imperio otomano entre los dos países y dio lugar a unas naciones artificiales en la zona, sin tener en cuenta las divisiones sectarias que ya existían.

${ }^{167}$ Arendt, Hannah, citado por GRÜNER, Eduardo, Las formas..., op. cit., p. I58

168 SCHMITT, Carl, Teología ..., op. cit., p. 18.

169 Éste es el marco/esquema (framework) que proponen JACKSON, Richard y DEXTER, Hellen, “The Social Construction of”, op. cit.

${ }^{170}$ Vattimo sostiene que el Zaratrusta de Nietzsche repele por su "estilo redundante, hinchado, <retórico> en el peor sentido, de muchas
} 
mundo de forma diferente al relato liberal ilustrado. El sentido no está en la Historia ni en las cosas, somos nosotros quienes lo adherimos a ellas ${ }^{171}$; el progreso de la humanidad es un concepto muy discutible; cualquier relato "Alfa y Omega" es una invención consoladora; la teleología no es posible sin la teología; y sin Dios — ser trascendente ahistórico, ahumano y todo poderoso- las bases del discurso de la Verdad, la Justicia, el Bien y el Mal, el cómo y porqué vivir, es decir, los fundamentos de la ética y del sentido del mundo y nuestra existencia desaparecen. Hay que volver a lo básico a lo existente: el Fenómeno de Husserl, el Dasein de Heidegger, la Nada de Sartre, etc. El sin sentido trascendente del sentido que nos deja solos con lo existente.

En teoría social y teoría política este hilo de negatividad creadora, que floreció, sobre todo, en la República de Weimar, sostiene que la búsqueda del Bien produce el Mal, un claro pensamiento nietzscheano; que la política es un pacto con el diablo ${ }^{172}$; que la ética sin Dios es pura estética ${ }^{173}$; que la violencia funda derecho, como ya hemos citado a Benjamin; que la enemistad es constitutiva de la identidad y que la posibilidad real de la violencia constituye la esencia de lo político y la "violencia cortante de la decisión" producto de la voluntad política al margen de la norma ${ }^{174}$; que abordar los problemas políticos como si fueran experimentos de las ciencias duras y/o cruzadas contra el Mal, es la receta certera para el desastre ${ }^{175}$; que "lo político en su sentido específico consiste en el particular grado de intensidad de la conexión creada por la voluntad de poder del estado entre sus objetos (objects) y el estado"176; que nos enfrentamos al eterno comienzo, donde las soluciones de hoy son el germen de los problemas de mañana; El mito de Sísifo de Camus 177; o que, como diría Sartre, "estamos condenados a elegir/a ser libres"178.

Richard Wolin ${ }^{179}$ relaciona a estos pensadores con el existencialismo y argumentó que "la devaluación de todos los valores tradicionales significó que la existencia humana, facticidad bruta se convierte en un valor en sí misma [...] este pensamiento alimenta la naturaleza no normativa del decisionismo, en sus variantes heideggerianas y schmittianas"'80.Schmitt traspasa la "suspensión teológica de lo ético" de Kierkegaard y de lo moral a la esfera de lo político, de tal manera que lo político tiene primacía sobre la legalidad. Por esta razón, Wolin acuña para Schmitt la etiqueta de decisionismo existencial ${ }^{181}$. Byung-Chul Han abunda en la misma idea para Schmitt; asimismo, para el Benjamin de "Para una crítica de la violencia", lo existencial ocupa el lugar de lo

páginas [...]”."¿Será sólo una cuestión de gusto de la época?, como parece pensar Hans Georg Gadamer, uno de los comentaristas que más explícitamente han reconocido estas graves limitaciones de la obra", se pregunta Vattimo. En VATTIMO, Gianni, Diálogos con Nietzsche. Ensayos 1961-2000, Paidós, Barcelona, 2002, p. 251.

${ }^{171}$ Aquí vamos más atrás que Nietzsche y nos estamos remitiendo a Hume.

${ }^{172}$ GONZÁLEZ GARCÍA, José María, “Metáforas del poder en la filosofía política”, en López de la Vieja, M.T. (ed.), Figuras del logos. Entre la filosofía y la literatura, FCE, México, 1994, p. 127

${ }^{173}$ WITTGENSTEIN, Ludwig, Tractatus logico-philosophicus..., op. cit. Permítasenos esta confusión (antimanual) de escuelas.

${ }^{174}$ Glosando a Carl Schmitt, HAN, Byung-Chul, Topología de..., op. cit., pp. 63 y ss.

175 MORGENTHAU, Hans, The Concept of..., op. cit.; MORGENTHAU, Hans, Scientific man..., op. cit.

176 Ibídem, p. 120

177 CAMUS, Albert, El mito de Sísifo, Alianza Editorial, Madrid, 2004.

${ }^{178}$ SARTRE, Jean-Paul, El existencialismo es un humanismo, Edhasa, Madrid, 2009 [1946], p. 24. Todos estos indicios de pensamiento tienen un "aire de familia" con el "pesimismo de la razón y el optimismo de la voluntad" de Gramsci.

${ }^{179}$ WOLIN, R., “Carl Schmitt, Political Existentialism and the Total State”, Theory and Society, vol. I9, n. 4, I990, pp. 389-4I6.

180 Ibídem, pp. 394 y ss.

${ }^{181}$ Ibíd., p. 398. 
normativo ${ }^{182}$. Estamos ante un existencialismo político (realista).

Para nosotros, este realismo político existencialista proporciona una lectura más plausible del antagonismo civilizatorio que ha sido tratado en estas páginas, que un relato de la tolerancia multicultural radical o un relato liberal ilustrado civilizado/salvaje o Mal/Bien. Sólo esta primacía de lo existente, de lo político, de la voluntad a pesar de todo, podría, quizá algún día, fructificar en un apaño aceptable.

\subsection{El mito de la ética universal y la defensa de los principios éticos.}

El punto anterior nos encauza sin remedio a la discusión ética sobre la universalidad moral o más propiamente a la discusión sobre la universalidad de determinado conjunto de principios éticos: aquellos que esgrimen los filósofos, medios y políticos del occidente liberal, de corte kantiano -más que menos vulgarizado. Cuestionar un tópico (en este caso el valor moral de la compasión) genera una nueva demanda político-teórica (una crítica de la moralidad en sí) que a su vez produce la necesidad de un nuevo tipo de conocimiento (un tipo particular de historia de la moralidad). Para emprender una crítica política de los valores, para cuestionar el valor de ciertos valores, hay que conocer las condiciones en las cuales emergieron, se transformaron y se difundieron; cómo convergieron todos los valores o los desplazaron y que combate puso en valor o a que fines sirvió la emergencia. Esta es la historia sepultada por la naturalización de los valores como universales y transhistóricos ${ }^{183}$.

Por su parte, este realismo político existencial - etiqueta que designa no un pensamiento coherente y cerrado, sino pensamientos diferentes de autores y en épocas y trayectorias vitales diversas, pero en el que identificamos hilos sustanciales comunes - no parece casar con universales ni teleologías: la derivación del concepto de justo e injusto no de la naturaleza de las cosas sino del derecho establecido por el Leviatán; los fundamentos falsos pero naturalizados que conforman la moral moderna que señala Nietzsche; los demonios de Weber y su ética consecuencialista; la violencia como fundadora de derecho de Benjamin; la primacía de la decisión sobre la norma en Schmitt; las leyes de la política distintas y de las normas éticas de Morgenthau; etc. cuestionan genealógicamente (en términos de Foucault) el origen de esa ética universal; filosóficamente lo consideran insustentable y políticamente peligroso.

Los imaginarios sociales modernos donde se construyen y reposan nuestras concepciones morales sobre lo político, el conflicto, el poder, la violencia, la organización de la comunidad política, el valor del ser humano y de la humanidad en sus concepciones modernas y occidentales, se han articulado históricamente, en el mundo de la tradición cristiana y luego moderna, sobre todo en relaciones internacionales, en torno a dos ejes: el primero, el eje comunidad-estadonación, es decir comunidad o humanidad; $y$, el segundo, el eje entre lo bárbaro y lo civilizado, o premoderno y lo moderno. Estos dos ejes definen y delimitan los intentos de construcciones de comunidades políticas y órdenes mundiales y los diferentes discursos descriptivos y normativos sobre estos procesos por lo menos desde el siglo XIX.

Así el valor moral de los seres humanos es definido en términos propios de uno de

\footnotetext{
182 HAN, Byung-Chul,Topología de..., op. cit., p. 67.

${ }^{183}$ BROWN, Wendy, La política fuera de la historia, Enclave de Libros, Madrid, 20 I4, p. I4I
} 
los extremos de nuestro primer eje: es decir la cosmópolis, la Humanidad una, constituida por múltiples individuos cuyo valor moral, basado en el concepto de dignidad humana ${ }^{184}$, es el punto arquimédico de cualquier construcción moral (o eso mantienen muchos de sus defensores). Pese a estar parcelados en diferentes comunidades políticas $y$, por tanto, que su felicidad o incluso su vida no valga - en la práctica - lo mismo, es absoluto e intrínseco a su misma humanidad. La violación de sus derechos, así como su institucionalización suelen ser examinados con el imaginario de los dos ejes mencionados y el resultado de tal análisis es siempre un discurso cuya idea central es el déficit: de estatalidad, de civilización, de modernidad, de accountability, de despatrimonialización de lo público, etc. Es decir, en términos de nuestro otro eje, como "atraso"185.

La unidad, el valor y la dignidad inmanentes de la humanidad traen aparejada la universalidad de los principios y de las concepciones éticas ${ }^{186}$. Este es el cimiento de la ética universal por ejemplo, los Derechos Humanos ${ }^{187}$ - y de su primacía sobre otros aspectos de la actividad humana. Este cimiento se asienta sobre un fundamento inencontrable una vez que retiramos al "Ser Transcendental" de la ecuación. La universalidad de una ética sin Dios es indemostrable.

Partiendo de estas premisas, la ausencia de un punto arquimédico (ni dios, ni polis, ni...) sobre el que fundamentar los sistemas ético-morales y la situación de estos sistemas en estos dos ejes mencionados, es bastante inteligible la consideración de los discursos — "sistemas de significación", "regímenes de verdad"|88_ éticos como contingentes histórica, geográfica y culturalmente. Esta es la senda abierta por Nietzsche.

En el debate en filosofía y/o teoría política sobre la ética de la acción humana, a partir de los años 70 cuando John Rawls publicó de A Theory of Justice ${ }^{189}$ y puso el debate ético sustantivo otra

${ }^{184}$ Según la lectura de Oliver Sensen sobre estos dos documentos de Naciones Unidas, la dignidad humana es un valor "inconmensurablemente más alto", "una propiedad con un valor ontológico diferente" y según estos dos documentos "los derechos humanos se derivan de la dignidad inherente de la persona humana y la Carta de NN.UU. vincula la dignidad a valor". SENSEN, Oliver, "Human dignity in historical perspective", European Journal Of Political Theory, vol. 190, $\mathrm{n}^{\circ}$ I, 201 I, pp. 72 y ss.

${ }^{185}$ SANTOS, B. de S, Descolonizar el saber, reinventar el poder, Trilce, Montevideo, 20I0, p. 22. El autor distingue cinco modos de producción de ausencia: el ignorante, el retrasado, el inferior, el local o particular y el improductivo y estéril.

${ }^{186}$ El concepto de Dignidad humana, según Oliver Sensen (SENSEN, Oliver, “Human dignity in ..., op. cit.) como fuente de los derechos humanos ha variado con el tiempo y sólo parece como la fuente de los derechos en el pensamiento contemporáneo (el autor llega a afirmar que en Kant tal concepto tiene más que ver con Cicerón que con la Carta y el Convenio de NN.UU.). Parece que incluso desde el campo de la filosofía del Derecho se reconoce esta historicidad básica de los derechos humanos. Según A. Pérez Luño), el hecho de que "los derechos humanos son una categoría histórica, es una idea hoy ampliamente compartida y que está idea se da en el tránsito a la modernidad (citando a Peces Barba, 1982) que desembocarían en las revoluciones burguesas del XVIII. Esto otorgaría a los derechos humanos un perfil ideológico definido de matriz individualista" (PÉREZ LUÑO,A., "Concepto y concepción de los de los derechos humanos <Acotaciones a la ponencia de Francisco Laporta>”, Doxa. Cuadernos de Filosofia el Derecho, n 4, 1987, p. 55. Más adelante, citando a E. Denninger (I987), sostiene que "la consideración histórica enseña que los derechos fundamentales no son la expresión, ni el resultado de una elaboración sistemática, de carácter racional y abstracto, sino respuestas normativas histórico-concretas a aquellas experiencias más insoportables de limitación y riesgos para la libertad” en PÉREZ LUÑO,A.“Concepto y concepción...”, op. cit., p. 62.

${ }^{187}$ Los derechos humanos, en nuestro parecer, no dejan de ser un constructo humano moderno, contingente histórica y geográficamente que no puede o no ha podido ser fundamentado filosóficamente. Por lo menos, en lo que a nosotros se nos alcanza. Pero utilizaremos un argumento de autoridad. En el mismo número citado aquí arriba de la revista Doxa, en contestación a la ponencia de Francisco Laporta, Eugenio Bulygin sostiene que "Se me podría reprochar que esta concepción de los derechos humanos los prive de cimientos sólidos y los deja al capricho de legislador positivo. Por lo tanto, la concepción positivista de los derechos humanos sería políticamente peligrosa. Sin embargo, no veo ventajas en cerrar los ojos a la realidad y postular un terreno firme donde no lo hay". En LAPORTA, Francisco, "Sobre el status ontológico de los derechos humanos", Doxa. Cuadernos de Filosofía el Derecho, $\mathrm{n}^{\circ}$ 4, 1987, pp. 83 y 84. Véase también PEÑAS ESTEBAN, Francisco Javier, "Derechos humanos e imaginarios sociales modernos. Un enfoque desde las relaciones internacionales", ISEGORÍA. Revista de Filosofía Moral y Política, vol. 54, 20I4, 545-574.

188 MILLIKEN, Jennifer, “The Study of Discourse in International Relations:A Critique of Research and Methods”, European Journal of International Relations vol. $5, n^{\circ} 2$, 1999, p. 229.

${ }^{189}$ RAWLS, John, Theory of Justice. Hay varias ediciones. La original es Harvard University Press, Harvard, I97I. 
vez sobre la mesa, se han distinguido dos posturas, dejado a parte el nihilismo ético, o la ética de fundamento religioso. Se distinguía entre liberales cosmopolitas - uno de los extremos de uno de los ejes que hemos señalado antes- de inspiración kantiana (muy matizada) que ponían todo el acento en el valor moral de los seres humanos y de la humanidad, en el individuo libre y racional, en lo humano, cuyo máximo representante era el propio Rawls, y comunitaristas (Maclntyre, que nos remitía a la polis y decretaba que había que elegir entre Aristóteles o Nietzsche ${ }^{190}$ para superar el pobre emotivismo moderno,Walzer, etc.) que ponían el énfasis, situaban el fundamento, de la ética en la comunidad donde el individuo nacía y desplegaba su vida. La teoría crítica y los mal llamados posmodernos se situaban, tras un largo perífrasis entre los primeros. De esta discusión, que no ha sido superada, en lo que conocemos, aunque sí abandonada, creemos que podrían extraerse cinco rasgos: el primero es obvio, fue, era y es un discusión dentro de la modernidad occidental; el segundo, es que es una discusión laica y secular, es decir, la fundamentación se busca en lo humano; el tercero, es una discusión que puede ser abandona por aburrimiento pero no porque haya argumentos concluyentes y definitivos (no hay nada definitivo en la historia humana); cuarto, hay una mayoría de teóricos y académicos que se decantan por una posición cosmopolita, rawlsiana, de un cosmopolitismo político no metafísico; $y$, cinco, acaba siendo una discusión sobre normas de convivencia, sobre todo a partir de la publicación de Rawls de Political Liberalism y "Justice as Fairness: Political not Metaphysical" ${ }^{191}$, no sobre las diferentes nociones del Bien, sino sobre la reglas procedimentales para la convivencia y el gobierno de esa comunidad con concepciones distintas sobre el Bien. Es decir, la discusión sobre la ética acaba siendo una discusión sobre las reglas políticas de la convivencia, de la autoridad, del poder o sea del estado.

Si examinamos esta misma discusión, pero en lo que respecta al ámbito de las relaciones internacionales, nos encontraremos tres grandes posiciones ${ }^{192}$ : cosmopolitas, realistas 0 comunitaristas fuertes, y lo que pudiéramos llamar siguiendo a Walzer moralidad de los estados. Los realistas fuertes, dejando al margen la moda de finales del XIX del darwinismo social, se preocupan por el estado y en última instancia, en el extremo que tanto gusta a los realistas existenciales - la excepción enseña más que la norma, la supervivencia del estado como defensor de la comunidad política ${ }^{193}$. Éste es su fundamento, obviamente este estado que representa a la comunidad política de haberlo es un fenómeno de origen moderno y occidental, desde luego no universal en el tiempo y en el espacio. De este fundamento, se derivan normas o consejos de prudencia política, de proporcionalidad de medios/fines y de, como hemos visto, mantenimiento de los conflictos en el ámbito de lo político pues los intereses de supervivencia de una estadocomunidad son tan legítimos como los de cualquier otro. Por su parte los cosmopolitas defienden que el fundamento de todo valor moral está en el individuo, dotado de derechos inalienables, $y$, ergo, en la humanidad.

\footnotetext{
190 MACINTYRE, A., Historia de la ética, Paidós, Barcelona, I99I.Y MACINTYRE, A. Tras la virtud, Crítica, Barcelona, 1984.

${ }^{191}$ RAWLS, John, Political Liberalism, op. cit., y RAWLS, John, “Justice as Fairness: Political not Metaphysical”, Philosophy \& Public Affairs, I 985 , vol. I4, núm. 3.

${ }^{192}$ Para una revisión de esta polémica ver PEÑAS ESTEBAN, Francisco Javier, Hermanos y enemigos. Liberalismo y relaciones internacionales, La Catarata, Madrid, 2003.

${ }^{193} \mathrm{Ni}$ Carr ni Morgenthau se hacen ilusiones de este acoplamiento sin fisuras entre estados y comunidades políticas. De hecho, este acoplamiento casi perfecto es extremadamente difícil de encontrar en la política mundial. Pero no entran en ese tema puesto que pondría sobre el tapete el derecho a la autodeterminación, la representatividad de los gobiernos, la legitimidad de la idea de estado (límites fronterizos, titularidad para la ciudanía, etc.). Si tuvieron en cuenta todo esto no podrían escribirlo. Para analizar un problema es necesario simplificar, partir de un supuesto que se sabe falso, para analizar otro problema. Lo contrario es escribir el libro que contiene todos los libros, tarea que ni Borges se atrevió a abordar.
} 
Beitz ${ }^{194}$, uno de sus representantes más destacados, habla de cosmopolitismo moral y cosmopolitismo institucional. El primero se refiere sólo a una posición ética para juzgar las relaciones intencionales y las políticas de los estados; el segundo, David Held ${ }^{195}$, por ejemplo, se plantea una institucionalización de esta preeminencia ética de la humanidad en la forma de un gobierno mundial.A nuestro juicio sus obras son más líneas políticas, propuestas de acción —bastante utópicas, por otra parte_ más que sistemas éticos. Lo que hemos llamado la línea de pensamiento ético de la moralidad de los estados reconoce el papel éticamente fundacional del individuo, pero no considera que pueda ser considerado al margen de su existencia en la comunidad. Reflexionan, por tanto, sobre las relaciones entre las comunidades políticas, entre los estados — que tiene un moral standing - en el caso de Walzer ${ }^{196}$, o entre los pueblos en el caso de Rawls ${ }^{197}$, aunque esto último es tramposo ${ }^{198}$. Pero lo que aquí nos interesa es que tanto el paradigma legalista de Walzer y/o los principios de justicia derivados de la posición originaria de Rawls, son muy semejantes y no van más allá de la práctica normal del sistema de estados realmente existente, de la Carta de Naciones Unidas o de esa idea de los principios del orden internacional que avanzaba Bull ${ }^{199}$. Es decir, lo que se plantea como principios éticos se quedan en normas consensuadas - más o menos- de comportamiento político de los estados, de prudencia, de proporcionalidad. Otra vez lo político, al final, desplaza a lo éticamente normativo. El realismo político existencial, atemperado por las normas de comportamiento político fruto de las experiencias, sobre todo bélicas, de los estados, queda como única alternativa al kantianismo.

Volviendo a nuestro hilo principal, lo que queremos decir a través de esta reflexión, es que si no existe posibilidad de fundar filosófica o prácticamente un universalismo ético, y el ejemplo de las diferencias civilizatorias entre los contendientes, por ejemplo, de Daesh y Occidente así parece indicarlo, habrá que buscar respuestas éticas más modestas, que primen la política —que es una posición ética, aunque no lo parezca - que no olviden la historia, y el poder, el dominio, el conflicto y la violencia en su despliegue, que sea consciente de la contingencia de los valores por los que merece la pena morir y matar y de la que se deduzcan formas de modus vivendi procedimentales si así se quiere- entre contrapuestas visiones del Bien.

194 BEITZ, C., Political Theory and International Relations, Princeton University Press, Princeton, 1979.

195 HELD, David, La Democracia y el Orden Global. Del Estado Moderno al Gobierno Cosmopolita, Barcelona y Buenos Aires, Ediciones Paidós Ibérica, 1997.

${ }^{196}$ WALZER, Michael, Just and Unjust Wars:A Moral Argument with Historical Illustrations, Basic Books, Londres, 1977.

${ }^{197}$ Hay dos textos con el mismo título The Law of the peoples. Uno es una conferencia en los Amnesty Lectures, publicado en Critical Inquiry. La referencia completa es RAWLS, John, "The Law of the peoples", Critical Inquiry, vol. 20, nI, I993, pp. 36-68. El otro es el mismo texto publicado como libro en 1999 (RAWLS, John, The law of the peoples, Harvard University Press, Cambridge, Mass. 1999). Este último que incluye las críticas, sobre todo de sus seguidores, al primer texto, es decir, incorpora, responde y rechaza, las críticas de Beitz, Pogge, etc. La crítica de estos es que Rawls sitúa en la posición originaria a representantes de los pueblos y no a los individuos que constituyen ese pueblo. El resultado es que de la posición originaria saldrán unos principios de justicia entre los pueblos y no unos principios de justicia entre los individuos, entre los individuos, para todo lo humano.

${ }^{198}$ Rawls hace una distinción entre pueblos y estados, no por los problemas señalados más arriba de falta de acoplamiento, sino por una razón, a nuestro modo de ver, simple: los estados- se refiere a los aparatos del estado- tienen sus propias lógicas e intereses, por eso los que acuden a la posición originaria son los representantes de los pueblos. La trampa es que, sin entrar en quienes son los pueblos y si estos tienen estados acoplados, estos pueblos son capaces demandar representantes a la posición originaria. Unos pueblos que mandan representantes diplomáticos reconocidos por otros representantes son para el reto de los teóricos de ética en las relaciones internacionales estados. Que el estado reconocido internacionalmente tenga o no unos aparatos que buscan sus propios intereses es una cuestión que nos remite otra vez a problemas que en este campo de la ética en las relaciones internacionales pueden ser tratados, so pena de abarcarlo todo, es decir, no decir nada.

${ }^{199}$ BULL, Hedley, The Anarchical Society..., op. cit. 


\subsection{Secular, secularismo y secularización}

Aunque aquí hemos trabajado con el concepto de secularización como algo dado y lo máximo que lo hemos puesto en cuestión es cuando lo hemos calificado de ficción operativa, Ya hemos dejado constancia de la influencia del trabajo de Ángela Iranzo sobre la secularización como una cuestión ocultada/ocultada en la Relaciones Internacionales ${ }^{200}$. En este mismo sentido Elisabeth Shakman Hurd plantea una genealogía del concepto y de su uso partiendo — para abrir boca - en los discursos de Bush en los que se refería a la lucha con el terror y a la invasión de Irak como un mandato divino ${ }^{201}$ — "una república secular realizando en mandato divino"- Cabe, quizá sea necesario, aquí poner en cuestión un concepto discutido que tan "alegremente" hemos usado en este trabajo.

Iranzo sostiene citando a Charles Taylor que la característica -el "indicador genealógico"202 — de la modernidad, una de sus (de la modernidad) características definitorias es una forma inédita de experimentar el decurso del tiempo. La modernidad es secular "no en el sentido más común y vago de la palabra que remite a una ausencia de religión, sino en el sentido de que la religión ocupa un lugar distinto, compatible con el principio de toda acción social tiene lugar en un tiempo profano" ${ }^{203}$. Es en este sentido —la religión está presente incluso se utiliza como justificante de una política ${ }^{204}$ - y, además, siguiendo a Schmitt, los conceptos políticos modernos son conceptos secularizados, es decir, hay una herencia religiosa en nuestra teoría política. La teleología del relato ilustrado no deja de ser una transcripción de la promesa de salvación ${ }^{205}$, pero se vive en un tiempo profano y secular, por lo que decimos que la secularización es, al menos, una ficción operativa y ponemos en énfasis en la operatividad.

Las condiciones particulares del siglo XVII y XIX, Revolución Francesa incluida, hicieron posible una interpretación de la secularización "como una nueva forma de entender el tiempo y la historia, convirtiéndose, como diría Koselleck, en una categoría hermenéutica de la filosofía de la historia" ${ }^{206}$. Una de las más importantes características de la secularización es la presunción de distinguir limpiamente entre asuntos transcendentales y asuntos temporales ${ }^{207}$. Charles Taylor distingue entre dos líneas del secularismo. El laicismo como "una ética política independiente" y la secularización de "terreno común" (common ground ${ }^{208}$ ). El término secular, tal y como lo hemos utilizado aquí, es ese laicismo. Taylor señal con acierto que éste "no viaja bien": definido y buscado fuera del contexto del descreimiento occidental se manifiesta como una

\footnotetext{
${ }^{200}$ IRANZO, Ángela, “Continuidades del...”, op. cit.

201 SHAKMAN HURD, Elisabeth, "The Political Authority of Secularism in International Relations”, European Journal of International Relations, vol. I2, núm. 2, 2004

${ }^{202}$ IRANZO, Ángela, “Continuidades del...”, op. cit., p. 130

203 TAYLOR, Charles, Imaginarios sociales modernos, Paidós, Barcelona, 2006, p. 223.

${ }^{204}$ Koselleck argumenta que "Hay estructuras que no pertenecen exclusivamente a nuestra historia del tiempo presente, hay constelaciones repetibles, efectos a largo plazo, actitudes arcaicas que perviven, regularidades en la serie de acontecimientos...”. Citado por Iranzo, Ángela, “Continuidades del...”, op. cit, p. 211.

${ }^{205}$ Asimismo, Koselleck también argumentaba que "Las expectativas de salvación quedan mundanizadas, la idea de salvación/redención es reemplazada por la idea de liberación y todos los desafíos de la existencia se resuelven a través del tiempo histórico”, Ibídem, p. I29.

${ }^{206}$ Citado en IRANZO, Ángela, “Continuidades del ...”, op. cit., p. I4I.

${ }^{207}$ SHAKMAN HURD, Elisabeth, “The Political Authority...,", op. cit., p. 238.

${ }^{208}$ El common ground judeo-cristiano es aquel en que los miembros de una comunidad política establecen una coexistencia pacífica y un orden político basado en las doctrinas comunes a todas las sectas cristianas. Pero este common ground sigue teniendo fronteras bien definidas
} 
imposición de una visión metafísica sobre otras a las que les resulta extraño (alien $)^{209}$.

Shakman Hurd apunta que "aquellos que no están de acuerdo con el trazado de la línea divisoria que hace el secularismo entre lo temporal y los transcendental la contemplan con desprecio" 210 y, citando a Ashis Nandy, sostiene que la academia moderna considera el fanatismo (zealotry) como retroceso al primitivismo y al tradicionalismo patológico, pero una mirada más atenta se percatara que es un producto colateral de la patología de la modernidad ${ }^{21}$. Lo que, en definitiva, nos deja con una mayor conciencia de a contingencia del secularismo, pero sin solución para el conflicto, dado que la tolerancia religiosa de Nandy es igual pensamiento de coexistencia de distintas visiones el bien, en un consenso procedimental solapado que es lo que Rawls propone.

\subsection{Relaciones de poder y/o relaciones de dominación no son lo mismo que violencia} Violencia es un concepto difícil delimitar. Puede ser polisémico. La Real Academia no nos ofrece gran cosa: nos remite al adjetivo violento y lo relaciona con el uso de la fuerza, punto y aparte. El diccionario de María Moliner es un poco más explícito: violencia es definido como "la utilización de fuerza en cualquier operación"; Violento "se aplica a cualquier cosa que ocurre con brusquedad o con extraordinaria fuerza o intensidad". Hay otras acepciones, pero no hacen al caso de la violencia política. Otro aspecto o palabra que debe merecer nuestra atención ${ }^{212}$ es coercer (impedir a alguien que haga cierta cosa), coerción (acción de reprimir por la fuerza) y coercitivo (se aplica a lo que sirve o se emplea para reprimir o no permitir).

En cualquier caso, es conveniente aceptar el consejo de Byung-Chul Han y distinguir violencia de relaciones de poder, técnicas de dominación, dispositivos (en términos de Foucault) ${ }^{213}$. Esta distinción puede dar lugar a tres problemas: en primer lugar, la historicidad, es decir, las distinciones no son lo mismo en un sistema capitalista mundial y un sistema de estados que, por ejemplo, en la Europa feudal del siglo XIII; en segundo lugar, ¿es lo mismo el uso actual de la violencia ya sea un ataque aéreo o de carros de combate, que una bomba suicida, que la amenaza del uso de la misma? ila amenaza del uso de la fuerza es lo mismo que el uso actual de la fuerza; y tercero, es el problema de la responsabilidad, o, dicho de otro modo, sólo se culpa a los responsables del uso de la violencia y no a los responsables de las estructuras de dominio — violencia, estructural, simbólica y objetiva- que muy frecuentemente son las causas subyacentes ${ }^{214}$ a la violencia directa tanto mítica como divina.

Así la violencia estructural de Galtung ${ }^{215}$ no capta la diferencia entre poder y violencia. El famoso triangulo de este autor distingue entre la violencia directa, la cual es visible, se concreta con comportamientos y responde a actos de violencia; la violencia estructural, que se centra en el conjunto de estructuras que no permiten la satisfacción de las necesidades y se concreta,

\footnotetext{
${ }^{209}$ TAYLOR, Charles, “Modes of Secularism”, en BHARGAVA, Rajeev, (ed.), Secularism and its Critics, Oxford University Press, Calcutta, I 998 , pp. 3I-53. Citado por SHAKMAN HURD, Elisabeth, “The Political Authority...”, op. cit.

${ }^{210}$ Ibídem, p. 246.

2I' NANDY, Ashis, "The Politics of Secularism and the Recovery of Religious Toleration" (1998), citado por SHAKMAN HURD, Elisabeth, "The Political Authority...", op. cit., p. 255.

${ }^{212}$ MOLINER, María, Diccionario del uso del español, vol. I y II, Gredos, Madrid, 1987.

${ }^{213}$ HAN, Byung-Chul, Topología de..., op. cit., p. II 7 y ss.

${ }^{214}$ En el esquema de JACKSON y DEXTER ("The social construction of...", op. cit.) hay estructuras, agentes y discursos legitimadores.

${ }^{215}$ GALTUNG, Johan, “Violence, ...”, op. cit.
} 
precisamente, en la negación de las necesidades; y la violencia cultural, la cual crea un marco legitimador de la violencia y se concreta en actitudes. En términos estrictos, para nosotros, sólo la primera es la que calificamos de violencia. Los nombres y etiquetas tienen su importancia y es comprensible que el uso (abusivo a nuestro parecer) que hace Galtung del término violencia, por más que sea comprensible puesto que quiere poner en énfasis en el carácter impositivo y represor de las estructuras de dominio.

Byung-Chul Han habla de la violencia sistémica de Bourdieu. Aunque creemos que se refiere a la violencia simbólica porque argumenta que "la cotidianidad es la afirmación de las relaciones de poder existentes. La violencia simbólica, sin necesidad de la violencia física se ocupa de que se perpetúe la dominación"'”216. En definitiva, naturaliza la dominación. Han cita a Bourdieu: "Todo poder tiene una dimensión simbólica: debe recibir un consentimiento de los dominados, que no remite a una decisión libre de una conciencia ilustrada, sino a la sumisión no mediada y prerreflexiva del cuerpo socializado"217. Por lo tanto, poder no es lo mismo que violencia, la dimensión del poder se ocupa de que el dominio se ejerza sin violencia: "Hay cosas sobre las cuales apenas existe toma de conciencia, sobre las cuales la conciencia apenas se percata, puesto que se sitúan al nivel de disposiciones corporales"218.

Slavoj Žižek distingue entre violencia subjetiva, intencionada y ejercida por un agente identificado claramente y violencia objetiva. En los términos aquí usados entre violencia y mecanismos o formas de dominio/autoridad. La violencia objetiva "es invisible pues es el estándar sobre el que nos sustentamos para percibir algo como subjetivamente violento. [...] es lo que la materia oscura en la física, la contraparte de la más que visible violencia subjetiva" ${ }^{219}$. Hay dos clases de violencia objetiva, la violencia simbólica incrustada en el lenguaje y sus formas ("our house of being" en términos de Heidegger que cita Žižek) y que impone un cierto universo de significado, y la violencia sistémica o, dicho de otro modo, "las consecuencias catastróficas frecuentes del funcionamiento de nuestros sistemas político y económico"220.

Para Žižek de lo que hablamos "[...] es de la violencia inherente en un sistema: no sólo la violencia física directa, sino también las formas más sutiles de coerción que sostiene las relaciones de dominación y explotación, incluida la amenaza de la violencia"221. Con el tema de la coerción y de su adjetivo coercitivo entramos en la zona gris donde las distinciones no pueden ser existenciales/ fenoménicas/fácticas sino sólo analíticas.Autoridad, poder, dominio, coerción, fuerza (amenaza y/o uso) y violencia pueden encontrase en un campo semántico solapado y enmarañado. La Carta de Naciones Unidas en el capítulo I, artículo 2, punto 4 equipara en su mandato de abstención la amenaza del uso de la fuerza con el uso actual. Es evidente que las estructuras de dominación coercen las actitudes y comportamientos y que detrás de esa coerción se sitúa la amenaza del uso de la fuerza o su uso real ${ }^{222}$. También es cierto que en ocasiones la amenaza del uso de la

\footnotetext{
${ }^{216}$ En HAN, Byung-Chul, Topología de..., op. cit., p. 119.

${ }^{217}$ Ibídem, p. I 19, y BOURDIEU, Pierre, La dominación masculina, Anagrama, Barcelona,2000, p. 9.

${ }^{218}$ BOURDIEU, Pierre, “Symbolic violence” (1995), reproducido en Revista Latina de Sociología, núm. 2, 2012 , p. 3.

${ }^{219}$ ŽIŽEK, Slavoj, Violence. Six sideways reflections, Picador, Nueva York, 2008, pp. I y 2.

${ }^{220}$ Ibídem, p. 2.

${ }^{221}$ Ibíd., p. 9

${ }^{222}$ Carta de Naciones Unidas, 1945. Cap. I, art. 2, punto 4:“Los Miembros de la Organización, en sus relaciones internacionales, se abstendrán
} 
fuerza no es creíble pues no tiene visos de materializarse en un uso real y una amenaza que no se cumple deja de ser amenaza. Si podemos o no, con Galtung, Bourdieu o Žižek, usar conceptos como violencia estructural, simbólica, sistémica u objetiva, dependerá del objeto de estudio.Aquí, en este trabajo nos hemos referido a violencia directa (militar) ejercida por todos los bandos en conflicto y hemos considerado útil aislar esta violencia, sin olvidar que detrás hay estructuras, símbolos, y sistemas.

\section{5 ¿Otros tipos - novedosos- de violencia?}

Como sostenía Charles Tilly, un reputado especialista en el papel constructor/destructor de la violencia política, y figura señera dela Sociología Histórica, después del I I-S, “ [...] sigo pensando que el terror es una estrategia política recurrente [...]" que es puesta en práctica por una gran variedad de actores y no un credo, otra variedad de lo político, o el resultado de las acciones de un grupo diferente y único (distinctive) de gente ${ }^{223}$, es una violencia que se muestra como otro medio de hacer política, de luchar por objetivos políticos. Parece que la violencia de los grupos yihadistas no es ontológicamente diferente a otras violencias ejercidas por otros grupos distintos en la historia y en la geografía. Las llamadas nuevas guerras no parecen ser tan nuevas. Eso sí, son distintas a la mayoría de los conflictos armados producidos durante la Guerra Fría. Pero ésta duró apenas 45 años. Los grupos yihadistas aplican fuerza letal en las metrópolis (como el FLN argelino) o en concentraciones de población "enemiga” (Bagdad, Damasco, Kabul, etc.). Por otro lado, el Daesh/Isis combate de forma convencional para el control de los territorios en disputa en Siria e Irak.

Algo que ha llamado la atención y que se califica (erróneamente de) nuevo es la privatización de la violencia armada. Las llamadas compañías privadas, es decir, con ánimo de lucro, de seguridad que cumplen funciones militares que les asignan los estados que las contratan. Funcionan igual y con los mismos fines que los condottieri italianos de los siglos XV y XVI. Es más, la mayoría de los ejércitos estatales de los príncipes de los siglos $\mathrm{XVI}$ al XIX eran tropas mercenarias. Es paradigmático, el caso de Albrecht Wenzel Eusebius von Wallenstein más conocido como Wallenstein oWaldstein (Heřmanice, 24 de septiembre de I583-Eger, 25 de febrero de 1634), fue un militar y político bohemio que se convirtió en un caudillo mercenario al servicio del emperador Fernando II contra los rebeldes protestantes y sus aliados suecos y daneses en la Guerra de los Treinta Años ${ }^{224}$. En el siglo XVIII y hasta medados del XIX proliferaron en las potencias europeas las chartered companies ${ }^{225}$ : desde el siglo $\mathrm{XVI}$ grupos de inversores europeos formaron compañías para sacar beneficios de la explotación de África - la trata, sobre todo-, India, Asia, el Caribe y América del Norte bajo el patronazgo de los estados que les expedían una Carta Real.Algunas de estas como la Compañía de las Indias Orientales británicas (para la que trabajo John Mill) poseían ejércitos propios y banderas y distintivos cuasi-estatales. Decayeron a raíz de Motín Indio de 1856 , que provocó que la corona británica se hiciera cargo del gobierno del subcontinente.A partir de

de recurrir a la amenaza o al uso de la fuerza contra la integridad territorial o la independencia política de cualquier Estado, o en cualquier otra forma incompatible con los Propósitos de las Naciones Unidas".

${ }^{223}$ TILLY, Charles, The Politics of Collective Violence, Cambridge University Press, Cambridge, 2003, p. XII

${ }^{224}$ Llegó a poseer un ejército de 30.000 a 100.000 hombres bajo su mando durante la guerra de los Treinta Años, y fue nombrado duque de Friedland y caballero del Toisón de Oro (1625), duque de Żagań (1627), así como duque de Mecklemburgo (I628-I63I) y Conde Palatino.

${ }^{225}$ COLÁS, Alejandro y MABEE, Bryan, (eds.), Mercenaries, Pirates, Bandits and Empires. Private Violence in Historical Context, C. Hurst \& Co. (Publishers), Ltd., Londres, 20 I0.Y THOMSON, J. E., Mercenaries, Pirates, and Sovereigns. State-building and Extraterritorial Violence in Early Modern Europe, Princeton University Press, Princeton, 1994. 
la Revolución Francesa y las guerras napoleónicas con sus reclutamientos masivos de ciudadanos, el estado fue adquiriendo el monopolio (legítimo) de la fuerza armada ${ }^{226}$. Estas compañías suponen la vuelta de los mercenarios - que, por otra parte, nunca desaparecieron-. La diferencia entre los mercenarios de los siglos XVI al XIX y los del siglo XXI. Es que los primeros respondían a la incapacidad de los estados para el reclutamiento masivo de su población, y lo de ahora al intento de evitar el síndrome de los body-bags. Los nuevos mercenarios proporcionados por las compañías de seguridad no hacen responder de sus atrocidades o delitos al estado, responsabilidad que no le queda más remedio que reconocer en el caso de sus tropas regulares.

\section{6 "Pánico" y securitización en las sociedades occidentales}

Uno de los teóricos críticos sobre el discurso de la War on Terror, Richard Jackson comienza su libro ${ }^{227}$ con una cita de la temprana novela de Coetzee Waiting for the barbarians: "En privado observo que una vez en cada generación, sin falta, hay un episodio de histeria sobre los bárbaros". 1963 y 1973 tuvieron su momento de histeria con el peligro de una guerra nuclear. En el año 2003, Bush, Blair y Aznar intentaron crear sin demasiado éxito un momento de histeria sobre las armas de destrucción masiva que almacenaba el régimen de Sadam Hussein. Pero ya dese el II de septiembre de 200 I se generó, no un momento, sino un estado de ánimo permanente de miedo a los atauques terroristas. Los atentados de Madrid y Londres consolidaron este miedo y finalmente en estos últimos años el miedo comenzó a convertirse en pánico tras los atentados de Paris y Bruselas. No es un miedo infundado, desde luego. Pero siguiendo a Grüner ${ }^{228}$ nos preguntamos ¿Cuál es el efecto del pánico sobre la subjetividad social? Nuestro autor identifica tres efectos ambivalentes. En primer lugar, el quiebro de solidaridad social, la ghettificación de las minorías previsiblemente futuras receptoras de atentados $y$, en estos años, futuro caldos de cultivo de yihadistas; en segundo lugar, la generación, como ya hemos mencionado, de un consenso para un mayor control por parte del poder y un mayor recorte de las libertades políticas; $y$, en tercer lugar, los efectos más sutiles de la "identificación de los sujetos sociales con el discurso que los interpela en su condición de víctimas potenciales [...] que requieren (cualquier) protección"229. Hay un cuarto efecto que Grüner no contempla: cualquiera que pone en cuestión el discurso oficial sobre el terrorismo, la doxa, es inmediatamente acusado de apología de aquel. El poder, como en otras muchas ocasiones, en casi todas, cierra las puertas a la comprensión de los problemas concretos en aras de una respuesta que aparezca como contundente, sin concesiones y sin disquisiciones vanas. Se niega así a entender, pues no hay nada que entender... ¡Hay que aniquilar! Nosotros creemos que esto no lleva a ninguna parte.

\subsection{La lejana solución}

¿La hay? ¿tolerancia? ¿modus vivendi? Estos son arreglos/acuerdos políticos, que no parecen alcanzables mientras el conflicto se relate en términos civilizatorios o teológicos $y$, por desgracia, hay base material para hacerlo así. Nos queda pensar que ha habido épocas en que las mismas condiciones objetivas no daban lugar a esta violencia generalizada... ¿jugará algún papel el agotamiento? Porque de lo contrario, no parece que pueda haber derrota definitiva sin aniquilación.

\footnotetext{
${ }^{226}$ SPRUYT, H., The Sovereign State and Its Competitors, Princeton University Press, Princeton, 1994.

${ }^{227}$ JACKSON, Richard, Writing the war on terrorism. Language, politics and counter-terrorism, Manchester University Press, Manchester, 2005 , p. 5.

${ }^{228}$ GRÜNER, Eduardo, Las formas de..., op. cit., pp. 94 y 95

${ }^{229}$ Ibídem, p. 94 y 95.
} 


\section{Bibliografía}

BADIOU,Alain, Nuestro mal viene de más lejos, Clave Intelectual, Madrid, 2016.

BALIBAR, Etienne, "What's in a War? (Politics as War, War as Politics)", Ratio Juris,Vol. 21, n 3, 2008, pp. 365-386.

BEHNKE, Andreas, "El Terror y lo Político: el II-S en el Contexto de la Globalización de la Violencia", Relaciones Internacionales, 2013, vol. 23, pp. II7-146.

BENJAMIN, Walter, Para una crítica de la violencia y otros ensayos, lluminaciones IV, Madrid, Taurus, 1998.

BEITZ, C., Political Theory and International Relations, Princeton University Press, Princeton, 1979.

BOURDIEU, Pierre, "Symbolic violence" (I995), reproducido en Revista Latina de Sociología, núm. 2, 2012, pp. I-4.

BOURDIEU, Pierre, Meditaciones Pascalianas, Anagrama, Barcelona, 2006.

BOURDIEU, Pierre, La dominación masculina, Anagrama, Barcelona, 2000.

BROWN,Wendy, La política fuera de la historia, Enclave de Libros, Madrid, 2014.

BULL, Hedley, The Anarchical Society. A Study of Order in World Politics, Palgrave, Nueva York, 2002 [1977].

BUZAN, Barry,W/EVER, Ole, deWILDE, Jaap, Security:A New Framework for Analysis, Lynne Rienner Publishers, Londres, 1998.

CAMUS, Albert, El mito de Sísifo, Alianza Editorial, Madrid, 2004.

CAÑON, Lisandro, “Terrorismo de estado. El sur del continente americano durante la década de 1970. Un caso de transnacionalización del terrorismo estatal", Revista de Relaciones Internacionales, núm. 32, 2016.

CARR, Edward H., The Twenty Years' Crisis: 1919-1939:An Introduction to the Study of International Relations, Harper and Row, Nueva York, 1939.

CASULLO, Nicolás, “La banalidad del bien”, en el Rodaballo, Revista de cultura y política, n. I, 1994.

COLÁS, Alejandro y MABEE, Bryan, (eds.), Mercenaries, Pirates, Bandits and Empires. Private Violence in Historical Context, C. Hurst \& Co. (Publishers), Ltd., Londres, 2010.

DE BENOIST,Alain, Carl Schmitt Today.Terrorism, "Just"War, and the State of Emergency, Arktos Media, Londres, 2013.

DERRIDA, Jacques, Fuerza de ley. El fundamento místico de la autoridad. Tecnos, Madrid, 2002.

ELIOT, John, Imperios del Mundo Atlántico. España y Gran Bretaña en América (1942-I 830), Santillana Ediciones Generales, S.L., Madrid, 2006.

ELLIOTT, John, The Old Word and the New, Cambridge University Press, Cambridge, 2003.

FOUCAULT, Michel, Historia de la sexualidad I. La voluntad de poder, Siglo XXI, Madrid, 2005.

FOUCAULT, Michel, Nietzsche, la genealogía y la historia, Pre-textos, Valencia, 1992.

FOUCAULT, Michel, Society must be defended, Penguin, Londres, 1975.

GALTUNG, Johan, “Violence, Peace and Peace Research", en Journal of Peace Research, vol. 6, n 3, 1969, pp. 167-191.

GONZÁLEZ GARCÍA, José María, “Metáforas del poder en la filosofía política”, en López de la Vieja, M.T. (ed.), Figuras del logos. Entre la filosofia y la literatura, FCE, México, 1994.

GRAY, John, Al Qaeda y lo que significa ser moderno. Paidós, Barcelona, 2004.

GRÜNER, Eduardo, Las formas de la espada, Ediciones Colihue, Buenos Aires, 1997.

HAN, Byung-Chul, Topología de la violencia, Herder, Barcelona, 2016.

HELD, David, La Democracia y el Orden Global. Del Estado Moderno al Gobierno Cosmopolita,

Barcelona y Buenos Aires, Ediciones Paidós Ibérica, 1997.

HINTZE, Otto, "La configuración de los estados y el desarrollo constitucional, Análisis histórico-político" (1902), reproducido en Relaciones Internacionales, núm. I, 2005, pp. I-19.

HOBSBAWM, Eric, Age of extremes. The short twentieth century, 19/4-1991. Abacus, Londres, 1994.

HÜLSSE, Rainer y SPENCER, Alexander, "The Metaphor of Terror:Terrorism Studies and the Constructivist Turn", Security Dialogue, vol. 39, n.o 6 (2008), pp. 57I-592.

HUNTINGTON, Samuel,“The clash of civilizations”, Foreign Policy, vol. 72, no. 3, 1993, pp. 22-49.

HUNTINGTON, Samuel, The clash of civilizations and the remaking of world order, Simon \& Schuster, Nueva York, 1996.

IRANZO, Ángela, "Continuidades del factor religioso en la historia de las relaciones internacionales. Reflexiones en torno a la narrative del 'resurgimiento de la religión' trás el II-S", tesis doctoral defendida en la Universidad Autónoma de Madrid.

JACKSON, Richard y DEXTER, Hellen, "The Social Construction of Organized Political Violence: An Analytical Framework", Civil Wars, vol. I6, n. I, 2014.

JACKSON, Richard et al., Terrorism:A Critical Introduction, Palgrave Macmillan, Nueva York, 20I I.

JACKSON, Richard, et al., Critical Terrorism Studies:A New Research Agenda, Routledge, London, 2009.

JACKSON, Richard, Writing the war on terrorism. Language, politics and counter-terrorism, Manchester University Press, Manchester, 2005.

KALDOR, Mary, New and Old Wars. Organized Violence in a Global Era, Stanford Universty Press, Stanford C.A., 1999.

LAPORTA, Francisco, "Sobre el status ontológico de los derechos humanos", Doxa. Cuadernos de Filosofia el Derecho, $n^{\circ} 4,1987$.

LOBO, Ramón, "EI mejor amigo del ISIS, nuestra estupidez, Infolibre, 22 de julio de 2016, http://www.infolibre.es/ noticias/opinion/2016/07/20/el_mejor_amigo_del_isis_nuestra_estupidez_52705_1023.html

LUKES, Steven, Power. A Radical View, Palgrave Macmillan, Nueva Ȳork, $20 \overline{0}$.

MANDEVILLE, Bernard, "La fábula de las abejas: o, vicios privados, beneficios públicos" en Roles sexuales: la mujer en la historia y la cultura, María José Rodríguez, E. Hidalgo y C.G.Wagner (eds), Ediciones clásicas, Madrid, 1994. 
MANN, Michael, The sources of social power,Vol. I, Cambridge University Press, Cambridge, 1986.

MANN, Michael, The Sources of Social Power. The Rise of Classes and Nation-States, I760-19/4, Cambridge University Press, Cambridge, 1993.

MARTINI, Alice, “El terrorismo global como amenaza al orden internacional. El caso del Estado Islámico”. Relaciones Internacionales, 2016, pp. 79-95.

MARTINI,Alice,“Terrorismo: un enfoque crítico”, Relaciones Internacionales, vol. 28, 2015, pp. I9I-199.

MARX, Karl, Una contribución a la crítica de la economía política, Editorial Progreso, Ciudad de México, 1989.

MAVELLI, Luca, "Between Normalisation and Exception: The Securitisation of Islam and the Construction of the Secular Subject”, Millenium:Journal of International Studies, vol. 4I, n² 2, 20I3, pp. I59-I8I.

MAVELLI, Luca, "Security and secularization in International Relations", European Journal of International Relations, vol. I8, $\mathrm{n}^{\circ}$ I, 2011, I77-199.

MACINTYRE, Alasdair, Tras la virtud, Crítica, Barcelona, 1997.

MACINTYRE,A., Historia de la ética, Paidós, Barcelona, I99I.Y MACINTYRE, A. Tras la virtud, Crítica, Barcelona, I984.

McGRANE, Bernard, Beyond Anthropology. Society and the Other, Columbia University Press, Nueva York, 1989.

MILBANK, J. P. L, “Against biopolitics”, Theory, Culture \& Society, 2008, 25 (7-8), I 25- 172.

MILLIKEN, Jennifer, "The Study of Discourse in International Relations:A Critique of Research and Methods", European Journal of International Relations vol. 5, $\mathrm{n}^{\circ} 2$, 1999, $225-254$.

MOLINER, María, Diccionario del uso del español, vol. I y II, Gredos, Madrid, 1987.

MORGENTHAU, Hans, The Concept of the Political, Palgrave Macmillan, Nueva York, 2012.

MORGENTHAU, Hans, Scientific man vs Power politics, Latimer House Limited, Londres, 1947.

MOUFFE, Chantal, Agonistics. Thinking the World Politically, Verso, Londres, 2013.

MOUFFE, Chantal, On the Political.Thinking in Action, Routledge, Nueva York, 2005.

NANDY,Ashis, "The Politics of Secularism and the Recovery of Religious Toleration", 1998.

NEGRETTO, Gabriel, L., “El Concepto de Decisionismo en Carl Schmitt: El Poder Negativo de la Excepción”, Sociedad, vol. 4, 1994

NIETZSCHE, Friedrich, La voluntad de poder, Biblioteca Edaf, Madrid, 20 I I [I90I].

NIETZSCHE, Friedrich, Genealogía de la moral,Alianza Editorial, Madrid, 1972.

PÉREZ LUÑO,A.,"Concepto y concepción de los de los derechos humanos <Acotaciones a la ponencia de Francisco Laporta>", Doxa. Cuadernos de Filosofia el Derecho, n 4, 1987.

PEÑAS ESTEBAN, Francisco Javier, "Derechos humanos e imaginarios sociales modernos. Un enfoque desde las relaciones internacionales", ISEGORÍA. Revista de Filosofia Moral y Política, vol. 54, 20I4, 545-574.

PEÑAS ESTEBAN, Francisco Javier, Hermanos y enemigos. Liberalismo y relaciones internacionales, La Catarata, Madrid, 2003.

PEÑAS ESTEBAN, Francisco Javier, “Estándard de civilización: las historias de las relaciones internacionales”, Revista Jurídica Universidad Autónoma de Madrid, n I, 1999.

PEÑAS ESTEBAN, Francisco Javier, Occidentalización, fin de la Guerra Fría y relaciones internacionales, Alianza Editorial, Madrid, 1997.

POLANYI, Karl, La gran transformación. Critica del liberalismo económico. La Piqueta, Madrid, 2007 [1947].

PROZOROV, Sergei, “Liberal Enmity:The Figure of the Foe in the Political Ontology of Liberalism”, Millennium: Journal of International Studies, vol. 35, $\mathrm{n}^{\circ} \mathrm{I}, 2006$.

RAINERI, Luca y MARTINI, Alice, "ISIS and AI-Qaeda as Strategies and Political Imaginaries in Africa:A Comparison between Boko Haram and Al-Qaeda in the Islamic Maghreb", Civil Wars, vol. I9, n 4, 20I7, pp. 425-447.

RAWLS, John, The law of the peoples, Harvard University Press, Cambridge, Mass. 1999.

RAWLS, John,"The Law of the peoples", Critical Inquiry, vol. 20, n I, 1993, pp. 36-68.

RAWLS, John, Political Liberalism. Columbia University Press, Nueva York, 1993.

RAWLS, John, Theory of Justice. Hay varias ediciones. La original es Harvard University Press, Harvard, I97I.

RAWLS, John, “Justice as Fairness: Political not Metaphysical”, Philosophy \& Public Affairs, I 985, vol. I4, n 3, 1985.

RUSSELL, Bertrand, Power, Unwin Books, Londres, 1975.

SANTOS, B. de S, Descolonizar el saber, reinventar el poder, Trilce, Montevideo, 2010.

SARTRE, Jean-Paul, El existencialismo es un humanismo, Edhasa, Madrid, 2009 [1946].

SHAKMAN HURD, Elisabeth, "The Political Authority of Secularism in International Relations", European Journal of International Relations, vol. 12, $\mathrm{n}^{\circ}$ 2, 2004.

SENSEN, Oliver, "Human dignity in historical perspective”, European Journal Of Political Theory, vol. 190, n I, 201 I.

SCHLESINGER, Arthur M., Los ciclos de la historia americana, Alianza Editorial, Madrid, 1988.

SCHMITT, Carl, La Dictadura, Alianza Editorial, Madrid, 2013 [1928].

SCHMITT, Carl, Teología política, Trotta, Madrid, 2009.

SCHMITT, Carl, The Concept of the Political. Expanded Edition. The University of Chicago Press, Chicago, 2007.

SCHMITT, Carl, The Theory of the Partisan.A Commentary/Remark on the Concept of the Political, Michigan State University Press: East Lansing, 2004

SMITH,Adam, Una investigación sobre la naturaleza y causas de la riqueza de las naciones, W. Strahan \& T. Cadell, Londres, 1776.

SPRUYT, H., The Sovereign State and Its Competitors, Princeton University Press, Princeton, 1994.

TAYLOR, Charles, Imaginarios sociales modernos, Paidós, Barcelona, 2006. 
TAYLOR, Charles, “Modes of Secularism”, en BHARGAVA, Rajeev, (ed.), Secularism and its Critics, Oxford University Press, Calcutta, 1998, pp. 31-53.

TILLY, Charles, The Politics of Collective Violence, Cambridge University Press, Cambridge, 2003.

TILLY, Charles, Coercion, Capital and European States, ad 990-1990, Basil Blackwell, Cambridge, 1990.

TILLY, Charles, "War-making and state-making as organized crime”, en EVANS, Peter, RUESDESCHEMEYER, Dietrich y SKOCPOL, Theda (eds.), Bringing the State Back In, Cambridge University Press, Cambridge, 1985.

THOMSON, J. E., Mercenaries, Pirates, and Sovereigns. State-building and Extraterritorial Violence in Early Modern Europe, Princeton University Press, Princeton, 1994.

TODOROV, Tzvetan, La conquista de América. El problema del otro, México, Siglo XXI, 1989.

VATTIMO, Gianni, Diálogos con Nietzsche. Ensayos I96 I-2000, Paidós, Barcelona, 2002.

Van CREVELD, Martin, The transformation of War, Free Press, Nueva York, I99I.

VERDES-MONTENEGRO ESCÁNEZ, Francisco Javier, "Securitización: agendas de investigación abiertas para el estudio de la seguridad”, Relaciones Internacionales, vol. 29, 20 I 5, pp. I I I- I3I.

WALKER, R. J.B., Inside/outside. International relations as political theory, Cambridge University Press, Cambridge, 1993.

WALTZ, Kenneth, Teoría de la política internacional, GEL, Buenos Aires, 1988.

WALZER, Michael, Spheres of Justice. A defense of pluralism and equality. Basic Books, Nueva York, 1983.

WEBER, Max, La ciencia como profesión. La política como profesión, Austral, Madrid, 1992.

WILLIAMS, Michael C., "Identity and the politics of security", European Journal of International Relations, vol. 4, n 2 , 1998, pp. 204-225.

WITTGENSTEIN, Ludwig, Tractatus logico-philosophicus, Alianza Editorial, Madrid, 2012 [192I].

WOLIN, R., "Carl Schmitt, Political Existentialism and the Total State”, Theory and Society, vol. 19, n 4, 1990, pp. 389416.

ŽlŽEK, Slavoj, La nueva lucha de clases. Los refugiados y el terror, Anagrama, Barcelona, 2016.

ŽlŽEK, Slavoj, Violence. Six sideways reflections, Picador, Nueva York, 2008. 


\section{RELACIONES INTERNACIONALES}

Revista académica cuatrimestral de publicación electrónica Grupo de Estudios de Relaciones Internacionales (GERI)

Universidad Autónoma de Madrid, España

https://revistas.uam.es/relacionesinternacionales

ISSN 1699 - 3950

f facebook.com/RelacionesInternacionales

3. twitter.com/RRInternacional 